\title{
Global model simulations of the impact of ocean-going ships on aerosols, clouds, and the radiation budget
}

\author{
A. Lauer ${ }^{1}$, V. Eyring ${ }^{1}$, J. Hendricks ${ }^{1}$, P. Jöckel ${ }^{2}$, and U. Lohmann ${ }^{3}$ \\ ${ }^{1}$ DLR-Institut für Physik der Atmosphäre, Oberpfaffenhofen, Germany \\ ${ }^{2}$ Max Planck Institute for Chemistry, Mainz, Germany \\ ${ }^{3}$ Institute of Atmospheric and Climate Science, Zurich, Switzerland
}

Received: 11 June 2007 - Published in Atmos. Chem. Phys. Discuss.: 2 July 2007

Revised: 10 September 2007 - Accepted: 21 September 2007 - Published: 4 October 2007

\begin{abstract}
International shipping contributes significantly to the fuel consumption of all transport related activities. Specific emissions of pollutants such as sulfur dioxide $\left(\mathrm{SO}_{2}\right)$ per $\mathrm{kg}$ of fuel emitted are higher than for road transport or aviation. Besides gaseous pollutants, ships also emit various types of particulate matter. The aerosol impacts the Earth's radiation budget directly by scattering and absorbing the solar and thermal radiation and indirectly by changing cloud properties. Here we use ECHAM5/MESSy1-MADE, a global climate model with detailed aerosol and cloud microphysics to study the climate impacts of international shipping. The simulations show that emissions from ships significantly increase the cloud droplet number concentration of low marine water clouds by up to 5\% to $30 \%$ depending on the ship emission inventory and the geographic region. Whereas the cloud liquid water content remains nearly unchanged in these simulations, effective radii of cloud droplets decrease, leading to cloud optical thickness increase of up to $5-10 \%$. The sensitivity of the results is estimated by using three different emission inventories for present-day conditions. The sensitivity analysis reveals that shipping contributes to $2.3 \%$ to $3.6 \%$ of the total sulfate burden and $0.4 \%$ to $1.4 \%$ to the total black carbon burden in the year 2000 on the global mean. In addition to changes in aerosol chemical composition, shipping increases the aerosol number concentration, e.g. up to $25 \%$ in the size range of the accumulation mode (typically $>0.1 \mu \mathrm{m}$ ) over the Atlantic. The total aerosol optical thickness over the Indian Ocean, the Gulf of Mexico and the Northeastern Pacific increases by up to $8-10 \%$ depending on the emission inventory. Changes in aerosol optical thickness caused by shipping induced modification of aerosol particle number concentration and chemical composition lead to a change in the shortwave radiation budget at the top of the atmosphere (ToA) under clear-sky condi-
\end{abstract}

Correspondence to: A. Lauer

(axel.lauer@dlr.de) tion of about $-0.014 \mathrm{~W} / \mathrm{m}^{2}$ to $-0.038 \mathrm{~W} / \mathrm{m}^{2}$ for a global annual average. The corresponding all-sky direct aerosol forcing ranges between $-0.011 \mathrm{~W} / \mathrm{m}^{2}$ and $-0.013 \mathrm{~W} / \mathrm{m}^{2}$. The indirect aerosol effect of ships on climate is found to be far larger than previously estimated. An indirect radiative effect of $-0.19 \mathrm{~W} / \mathrm{m}^{2}$ to $-0.60 \mathrm{~W} / \mathrm{m}^{2}$ (a change in the atmospheric shortwave radiative flux at ToA) is calculated here, contributing $17 \%$ to $39 \%$ of the total indirect effect of anthropogenic aerosols. This contribution is high because ship emissions are released in regions with frequent low marine clouds in an otherwise clean environment. In addition, the potential impact of particulate matter on the radiation budget is larger over the dark ocean surface than over polluted regions over land.

\section{Introduction}

Besides gaseous pollutants such as nitrogen oxides $\left(\mathrm{NO}_{\mathrm{x}}=\mathrm{NO}+\mathrm{NO}_{2}\right)$, carbon monoxide $(\mathrm{CO})$ or sulfur dioxide $\left(\mathrm{SO}_{2}\right)$, ships also emit various types of particulate matter (Eyring et al., 2005a). Due to low restrictive regulations for international shipping and the use of low quality fuel by most ocean-going ships, shipping contributes for example to around $8 \%$ to the present total anthropogenic $\mathrm{SO}_{2}$ emissions (Olivier et al., 2005). The aerosol impacts the Earth's radiation budget directly by scattering and absorbing solar and thermal radiation and indirectly by changing cloud properties. Aerosols emitted by ships can be an additional source of cloud condensation nuclei $(\mathrm{CCN})$ and thus possibly result in a higher cloud droplet concentration (Twomey et al., 1968). The increase in cloud droplet number concentration can lead to an increased cloud reflectivity. Measurements in the Monterey Ship Track Experiment confirmed this hypothesis (Durkee et al., 2000; Hobbs et al., 2000). This mechanism can also cause anomalous cloud lines, so-called ship tracks, which have often been observed in satellite data (e.g.

Published by Copernicus Publications on behalf of the European Geosciences Union. 
Conover, 1966; Nakajima and Nakajima, 1995; Schreier et al., 2006). In addition, aerosols from shipping might also change cloud cover and precipitation formation efficiency as well as the average cloud lifetime.

Although a rapid growth of the world sea trade and hence increased emissions from international shipping are expected in the future (Eyring et al., 2005b), the potential global influence of aerosols from shipping on atmosphere and climate has received little attention so far. Available studies on the global impact of ship emissions on climate concentrate on greenhouse gases such as carbon dioxide $\left(\mathrm{CO}_{2}\right)$, methane $\left(\mathrm{CH}_{4}\right)$ or ozone $\left(\mathrm{O}_{3}\right)$ as well as the direct effect of sulfate particles (e.g. Lawrence and Crutzen, 1999; Endresen et al., 2003; Eyring et al., 2007). Concerning the indirect aerosol effect by ship emissions, only rough estimates for sulfate plus organic material particles from global model simulations without detailed aerosol and cloud physics (Capaldo et al., 1999) are currently available. The overall indirect effect due to international shipping taking into account aerosol nitrate, black carbon, particulate organic matter and aerosol liquid water in addition to sulfate as well as detailed aerosol physics and aerosol-cloud interaction has not been assessed in a fully consistent manner yet.

The emissions of gaseous and particulate pollutants scale with the fuel consumption of the fleet. Ideally, the fuel consumption of the world-merchant ships calculated from energy statistics (Endresen et al., 2003; Dentener et al., 2006) and based on fleet activity (Corbett and Köhler, 2003; Eyring et al., 2005a) should be the same, but there are large differences between the two approaches and there is an ongoing discussion on its correct present-day value (Corbett and Köhler, 2004; Endresen et al., 2004; Eyring et al., 2005a). In addition, various vessel traffic densities have been published over the last years. In order to address these uncertainties, we apply three different emission inventories for shipping (Eyring et al., 2005a; Dentener et al., 2006, Wang et al., $2007^{1}$ ). We use the global aerosol climate model ECHAM5/MESSy1-MADE, hereafter referred to as E5/M1-MADE, that includes detailed aerosol and cloud microphysics to study the direct and indirect aerosol effects caused by international shipping. The model and model simulations are described in Sect. 2. To evaluate the performance of E5/M1-MADE we have repeated the extensive intercomparison of the previous model version ECHAM4/MADE with observations (Lauer et al., 2005). The comparison to observations shown here focuses on marine regions and is summarized in Sect. 3. Section 4 presents the model results and Sect. 5 closes with a summary and conclusions.

\footnotetext{
${ }^{1}$ Wang, C., Corbett, J. J., and Firestone, J.: Improving Spatial Representation of Global Ship Emissions Inventories, Environ. Sci. Technol., under review, 2007.
}

\section{Model and model simulations}

\subsection{ECHAM5/MESSy1-MADE (E5/M1-MADE)}

We used the ECHAM5 (Roeckner et al., 2006) general circulation model (GCM) coupled to the aerosol microphysics module MADE (Ackermann et al., 1998) within the framework of the Modular Earth Submodel System MESSy (Jöckel et al., 2005) to study the impact of particulate matter from ship emissions on aerosols, clouds, and the radiation budget. E5/M1-MADE is a further development of ECHAM4/MADE (Lauer et al., 2005; Lauer and Hendricks, 2006) on the basis of ECHAM5/MESSy1 version 1.1 (Jöckel et al., 2006). Aerosols are described by three lognormally distributed modes, the Aitken (typically smaller than $0.1 \mu \mathrm{m}$ ), the accumulation (typically 0.1 to $1 \mu \mathrm{m}$ ) and the coarse mode (typically larger than $1 \mu \mathrm{m}$ ). Aerosol components considered are sulfate $\left(\mathrm{SO}_{4}\right)$, nitrate $\left(\mathrm{NO}_{3}\right)$, ammonium $\left(\mathrm{NH}_{4}\right)$, aerosol liquid water, mineral dust, sea salt, black carbon (BC) and particulate organic matter (POM). The simulations of the aerosol population take into account microphysical processes such as coagulation, condensation of sulfuric acid vapor and condensable organic compounds, particle formation by nucleation, size-dependent wet (Tost et al., 2006) and dry deposition including gravitational settling (Kerkweg et al., 2006a), uptake of water and gas/particle partitioning of trace constituents (Metzger et al., 2002) as well as liquid phase chemistry calculated by the module SCAV (Tost et al., 2007). Basic tropospheric background chemistry $\left(\mathrm{NO}_{\mathrm{x}}-\mathrm{HO}_{\mathrm{x}}-\mathrm{CH}_{4}-\mathrm{CO}-\mathrm{O}_{3}\right)$ and the sulfur cycle are considered as calculated by the module MECCA (Sander et al., 2005). Aerosol optical properties are calculated from the simulated aerosol size-distribution and chemical composition for the solar and thermal spectral bands considered by the GCM. These are used to drive the radiation module of the climate model. Aerosol activation is calculated following Abdul-Razzak and Ghan (2000). Activated particles are used as input for a microphysical cloud scheme (Lohmann et al., 1999; Lohmann, 2002) replacing the original cloud module of the GCM. The fractional cloud cover is diagnosed from the simulated relative humidity (Sundqvist et al., 1989). In principle, the microphysical cloud scheme is able to capture both, the first and second indirect aerosol effect. The precipitation formation efficiency is linked to the calculated cloud droplet number concentration applying the formulation of Khairoutdinov and Kogan (2000). However, the effect of aerosol emissions on cloud life-time resulting from changes in the precipitation formation efficiency cannot be resolved accurately by the model. Cloud life-time is limited to a multiple of the time step length of the GCM ( $30 \mathrm{~min}$ in the configuration used). Thus, small changes in average cloud life-time cannot be resolved. Moreover, GCMs do not capture the microphysical processes in detail which could cause different responses in cloud properties to aerosol increases than obtained by detailed cloud models, e.g. Ack- 
erman et al. (2004). Details of the selected gas phase and aqueous phase chemical mechanisms (including reaction rate coefficients and references) as well as the namelist settings of the individual modules can be found in the electronic supplement (http://www.atmos-chem-phys.net/7/5061/2007/ acp-7-5061-2007-supplement.zip).

\subsection{Model simulations}

The impact of shipping is estimated by calculating the differences between model experiments with and without taking shipping into account. In order to obtain significant differences with a reasonable number of model years, model dynamics have been nudged using operational analysis data from the European Centre for Medium-Range Weather Forecasts (ECMWF) from 1999 to 2004. Sea surface temperature (SST) and sea ice coverage are prescribed according to the ECMWF operational analysis data, which are based on data products from the National Centers for Environmental Prediction (NCEP). The results have been averaged over all six years to reduce the effects of inter-annual variability. The signal from shipping is considered to be significant if the t-test applied to the annual mean values for this period provides significance at a confidence level of $99 \%$. All simulations discussed here were conducted in $\mathrm{T} 42$ horizontal resolution (about $2.8^{\circ} \times 2.8^{\circ}$ longitude by latitude of the corresponding quadratic Gaussian grid) with 19 vertical, nonequidistant layers from the surface up to $10 \mathrm{hPa}(\sim 30 \mathrm{~km})$.

To estimate uncertainties in present-day emission inventories (see Sect. 1), we performed three present-day model experiments using the ship emissions from Eyring et al. (2005a) (hereafter "inventory A"), Dentener et al. (2006) (hereafter "inventory B") and Wang et al. (2007) ${ }^{1}$ (hereafter "inventory C"). In addition, a reference simulation was carried out neglecting ship emissions. The emissions of all other trace gases except for $\mathrm{SO}_{2}$ and dimethyl sulfide (DMS) are taken from the Emission Database for Global Atmospheric Research EDGAR 3.2 FT2000 (Olivier et al., 2005), primary aerosols and $\mathrm{SO}_{2}$ from Dentener et al. (2006).

In inventory A emissions are estimated from the fleet activity (Eyring et al., 2005a), resulting into $\mathrm{SO}_{2}$ emissions of $11.7 \mathrm{Tg}$ for the world fleet in 2000 . This estimate is based on statistical information of the total fleet above 100 gross tons (GT) from Lloyd's (2002), including cargo ships (tanker, container ships, bulk and combined carriers, and general cargo vessels), non-cargo ships (passenger and fishing ships, tugboats, others) as well auxiliary engines and the larger military vessels (above $300 \mathrm{GT}$ ). The emissions are distributed over the globe according to reported ship positions from the Automated Mutual-assistance Vessel Rescue system (AMVER) data set (Endresen et al., 2003). In inventory $\mathrm{B}$ emission estimates are based on fuel consumption statistics (Dentener et al., 2006) with $\mathrm{SO}_{2}$ emission totals of $7.8 \mathrm{Tg}$ per year, and the geographic distribution considers the main shipping routes only. Inventory $\mathrm{C}$ takes into ac- count emissions from cargo and passenger vessels only, totaling 9.4 Tg SO 2 per year (Corbett and Köhler, 2003) and the geographical distribution follows the International Comprehensive Ocean-Atmosphere Data Set (ICOADS) (Wang et al., $2007^{1}$ ). Inventories A and B provide annual average emissions whereas inventory $\mathrm{C}$ provides monthly averages. While the geographic distribution in inventory B considers the main shipping routes only, the geographic distribution in inventory A (AMVER) and inventory C (ICOADS) are based on shipping traffic intensity proxies. These inventories therefore better represent actual shipping movements, and are to date considered the two "best" global ship traffic intensity proxies to be used for a top-down approach (Wang et al., $2007^{1}$ ). However, a comparison by Wang et al. (2007) $)^{1}$ also shows that both ICOADS and AMVER have statistical biases and neither of the two data sets perfectly represents the world fleet and its activity. Therefore we use both of them to estimate the uncertainties stemming from the ship emission inventory used.

The primary particles $\left(\mathrm{BC}, \mathrm{POM}\right.$, and $\mathrm{SO}_{4}$ ) from shipping are assumed to be in the size-range of the Aitken mode, which is typically being observed for fossil fuel combustion processes. Emissions of DMS and sea salt are calculated from the simulated $10 \mathrm{~m}$ wind speed (Kerkweg et al., 2006b). Table 1 summarizes the annual emission totals for particulate matter (PM) and trace gases emitted by shipping as considered in this study.

As an example, annual emissions of $\mathrm{SO}_{2}$ from international shipping in the three different emission inventories are displayed in Fig. 1. A major amount of $\mathrm{SO}_{2}$ from shipping is emitted within a band in the Northern Hemisphere covering the highly frequented shipping routes between the eastern United States and Europe as well as between Southeast Asia and the west coast of the USA. In general emissions are low in the Southern Hemisphere. Differences between the emission data sets are found particularly in the Gulf of Mexico, in the Baltic, and in the northern Pacific. The Eyring et al. (2005a) inventory gives the highest emissions of all three inventories in the Gulf of Mexico. The Dentener et al. (2006) inventory shows higher $\mathrm{SO}_{2}$ ship emissions in the Baltic compared to inventories A and C. Wang et al. (2007) ${ }^{1}$ suggested higher emissions in the northern Pacific compared to the two other inventories.

\section{Comparison to observations}

The extensive intercomparison of the previous model version ECHAM4/MADE with observations (Lauer et al., 2005) has been repeated with E5/M1-MADE. This intercomparison demonstrated that the main conclusions on the model quality (Lauer et al., 2005) hold for the new model system. In particular, the main features of the observed geographical patterns, seasonal cycle and vertical distribution of the basic aerosol parameters are captured. In addition to the comparison 


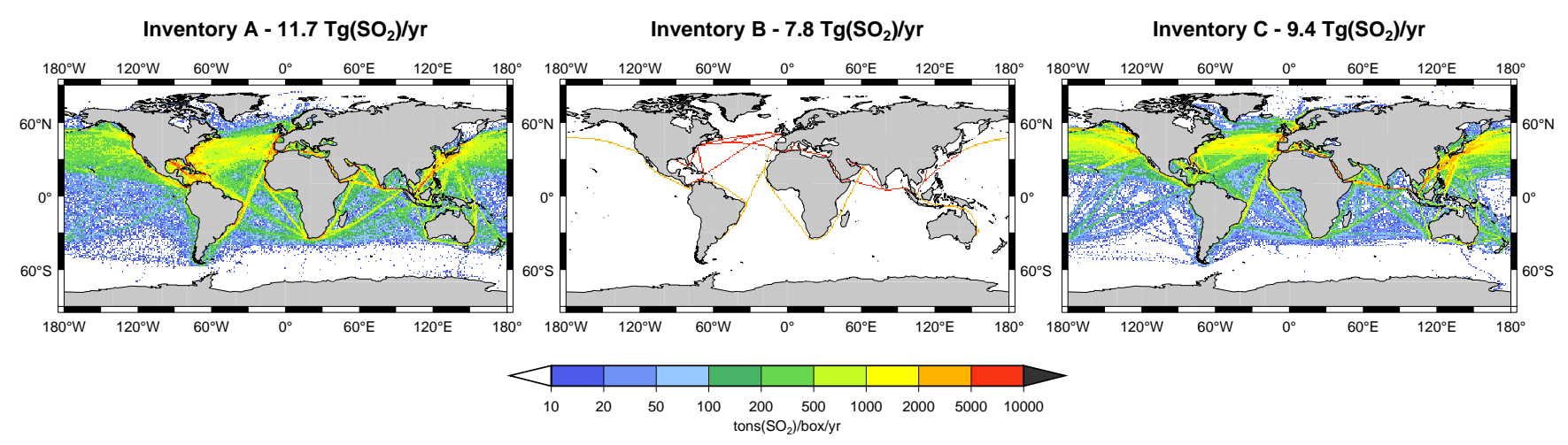

Fig. 1. Annual emissions of $\mathrm{SO}_{2}$ from international shipping in tons per $1^{\circ} \times 1^{\circ}$ box. Left: Inventory A (Eyring et al., 2005a), totaling 11.7 $\mathrm{Tg} \mathrm{yr}^{-1}$, middle inventory B (Dentener et al., 2006), totaling $7.8 \mathrm{Tg} \mathrm{yr}^{-1}$, left inventory C (Wang et al., $2007^{1}$ ), totaling 9.4 $\mathrm{Tg} \mathrm{yr}^{-1}$.
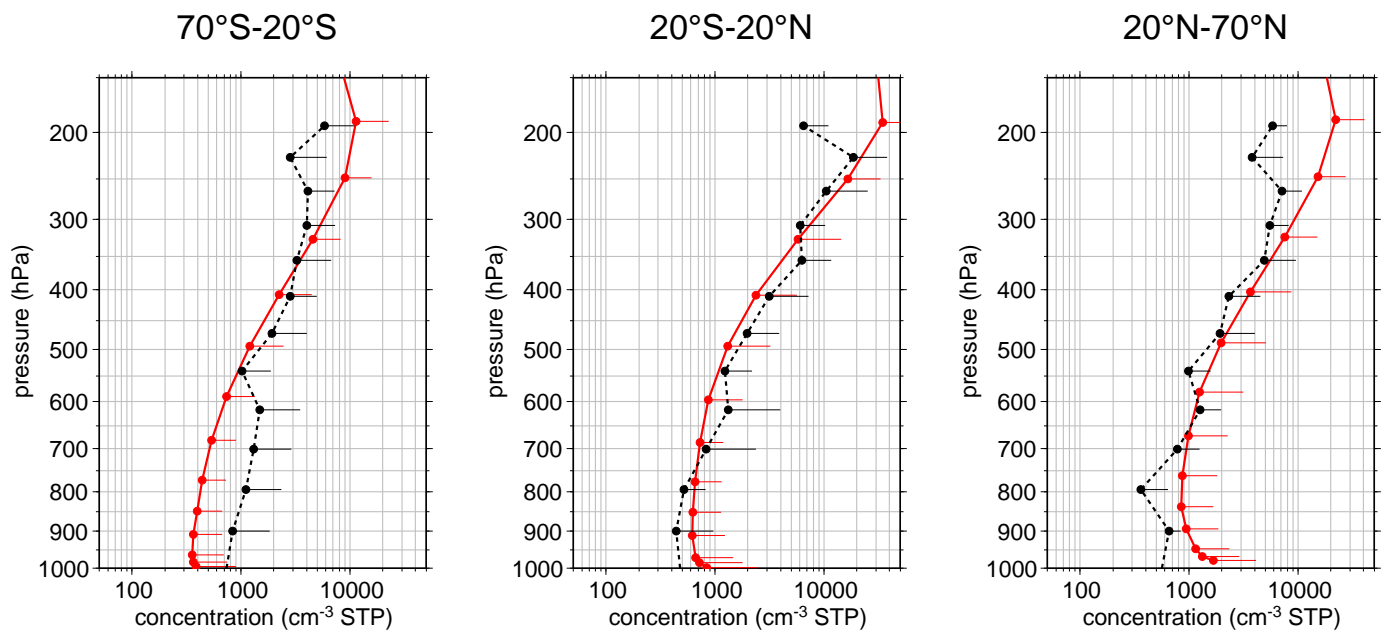

ECHAM5/MESSy1-MADE $(\geq 0.003 \mu \mathrm{m})$

$\cdots \cdot$ Observations UCN $(0.003-3.0 \mu \mathrm{m})$

Fig. 2. Vertical profiles of mean aerosol number concentrations in $\mathrm{cm}^{-3}$ (STP conditions: $273 \mathrm{~K}, 1013 \mathrm{hPa}$ ) obtained from various measurement campaigns over the Pacific Ocean (dashed; Clarke and Kapustin, 2002) and ECHAM5/MESSy1-MADE (solid) for the three latitude bands $70^{\circ} \mathrm{S}-20^{\circ} \mathrm{S}, 20^{\circ} \mathrm{S}-20^{\circ} \mathrm{N}$, and $20^{\circ} \mathrm{N}-70^{\circ} \mathrm{N}$. The bars depict the standard deviations (positive part shown only).

shown in Lauer et al. (2005), the cloud forcing and aerosol optical thickness of the E5/M1-MADE simulation have been compared to ERBE (Earth Radiation Budget Experiment) satellite data (Barkstrom, 1984) and Aeronet (Holben et al., 1998) measurements showing reasonable good agreement in most parts of the world, including the marine areas where the largest effects of shipping are simulated. In the following subsections, we show an intercomparison of model results from E5/M1-MADE using ship emission inventory A with observations focusing on marine regions. The differences between the model results using inventory A and inventories B and $\mathrm{C}$ are rather small. It should be noted that with this evaluation we mainly evaluate the performance of the model to simulate the background atmosphere, rather than the largescale effects (i.e. scales comparable to the size of the GCM's grid boxes) of shipping. The shipping signal cannot be easily evaluated by single-point measurements (see also (see also Eyring et al., 2007). Processes such as long-range transport of pollutants from continental areas or natural processes are often predominant, in particular in areas close to coast. Nevertheless, this intercomparison unveils strengths and weaknesses of the model to reproduce basic observed features relevant when assessing the impact of shipping, in particular over the oceans.

\subsection{Particle number concentration}

Clarke and Kapustin (2002) compiled vertical profiles of mean particle number concentration of particles greater than $3 \mathrm{~nm}$ from several measurement campaigns focusing on regions above the Pacific Ocean. The data include 
measurements performed during ACE-1, GLOBE-2, and PEM-Tropics A and $\mathrm{B}$. The data have been divided into the 3 latitude bands $70^{\circ} \mathrm{S}-20^{\circ} \mathrm{S}, 20^{\circ} \mathrm{S}-20^{\circ} \mathrm{N}$, and $20^{\circ} \mathrm{N}-70^{\circ} \mathrm{N}$ covering longitudes between about $130^{\circ} \mathrm{E}$ and $70^{\circ} \mathrm{W}$. Most of the measurements are taken over the ocean far away from the major source regions of aerosols above the continents. The variability of the particle number concentrations is given by the standard deviation. Figure 2 shows the comparison of these data to the simulated particle number concentration profiles extracted for the months covered by the measurements. The model data were averaged over all grid cells within the individual latitude bands.

The observed particle number concentration increases from the surface to the upper troposphere indicative of new particle formation in the upper troposphere. This is most pronounced at tropical latitudes due to strong nucleation taking place in the upper tropical troposphere. These basic features of the vertical profile of the particle number concentration are reproduced by the model. In the lower troposphere of the Southern Pacific (Fig. 2, left panel), E5/M1-MADE underestimates the mean particle number concentration, which could be related to the omission of sea salt particles in the size range of the Aitken mode in the model. We also compared the model data to measurements obtained during the campaign INCA (Interhemispheric Differences in Cirrus Properties from Anthropogenic Emissions, not shown) (Minikin et al., 2003). These measurements provide vertical profiles of the aerosol number concentration in the Southern Hemisphere for 3 different lower cut-off diameters. This comparison showed, that in particular the Aitken mode $(\mathrm{d}>14 \mathrm{~nm})$ and the accumulation mode $(\mathrm{d}>120 \mathrm{~nm})$ particle number concentrations calculated by the model nicely fit the observations, i.e. the modeled particle number concentration lies completely within the $25 \%$ and $75 \%$ percentiles of the observations up to about $500 \mathrm{hPa}$ (Aitken mode) and up to $350 \mathrm{hPa}$ (accumulation mode). For cloud formation in particular these size-regimes are relevant, whereas the very small particles that often dominate the total aerosol number concentration are less important. For this reason, we think that the model should be able to capture the indirect aerosol effect in the Southern Hemisphere reasonably well. This is further confirmed by the quite good agreement of cloud droplet number concentrations calculated by the model and retrieved from satellite observations for low marine clouds in this region as discussed in Sect. 3.4. In the tropics (Fig. 2, middle panel) and the northern Pacific (Fig. 2, right panel), the model results are mostly within the variability of the measurements, given by the standard deviations.

\subsection{Aerosol optical thickness (AOT)}

Figure 3 shows the multi-year average seasonal cycle of the aerosol optical thickness (AOT) at $550 \mathrm{~nm}$ calculated by E5/M1-MADE and measured by ground based Aeronet stations (1999-2004 where data available) (Holben et al., 1998)
Table 1. Annual emission totals of particulate matter and trace gases from shipping in $\mathrm{Tg} \mathrm{yr}^{-1}$ for the year 2000. Values are given for emission inventories A (Eyring et al., 2005a), B (Dentener et al., 2006), and C (Wang et al., 2007 ${ }^{1}$ ) as considered in this study.

\begin{tabular}{|c|c|c|c|}
\hline Compound & Inventory A & Inventory B & Inventory $\mathrm{C}$ \\
\hline $\mathrm{SO}_{2}$ & 11.7 & $7.6^{\mathrm{a}}$ & $9.2^{\mathrm{a}}$ \\
\hline $\mathrm{NO}_{\mathrm{x}}\left(\right.$ as $\mathrm{NO}_{2}$ ) & 21.3 & $9.6^{\mathrm{b}}$ & 16.4 \\
\hline $\mathrm{CO}$ & 1.28 & $0.10^{\mathrm{b}}$ & 1.08 \\
\hline primary $\mathrm{SO}_{4}$ & 0.77 & $0.29^{\mathrm{a}}$ & $0.35^{\mathrm{a}}$ \\
\hline $\mathrm{BC}$ & 0.05 & 0.13 & 0.07 \\
\hline POM & 0.13 & 0.06 & $0.71^{\mathrm{c}}$ \\
\hline
\end{tabular}

a $2.5 \%$ of $\mathrm{SO}_{2}$ mass emitted is assumed to be released as primary $\mathrm{SO}_{4}$

b Olivier et al. (2005)

c $60 \%$ of total PM mass emitted is assumed to consist of POM

for various small islands located in the Pacific (Tahiti, Coconut Island, Midway Island, Lanai), the Atlantic (Azores, Capo Verde), and the Indian Ocean (Amsterdam Island, Kaashidoo, Male). These locations are considered to be basically of marine character. For comparison, also satellite data from MODIS (2000-2003) (Kaufman et al., 1997; Tanre et al., 1997), MISR (2000-2005) (Kahn et al., 1998; Martonchik et al., 1998) and a composite of MODIS, AVHRR and TOMS data (Kinne et al., 2006) are shown, as well as the median of several global aerosol models (Kinne et al., 2006) which provided AOT for the AeroCom Aerosol Model Intercomparison Initiative (Textor et al., 2006). The Aeronet data used are monthly means of level 2.0 AOT, version 2 . The AOT data at $550 \mathrm{~nm}$ have been linearly interpolated from the nearest wavelengths with measurement data available.

For the Pacific measurement sites Coconut Island, and Lanai as well as for the Indian Ocean site Amsterdam Island and the Atlantic Ocean site Azores, the simulated AOT are mostly within the inter-annual variability of the Aeronet measurements, given by the standard deviation.

According to the geographical distribution of the ship traffic density (Fig. 3), the measurement sites Coconut Island, Lanai, Kaashidoo, Male, Azores, and Capo Verde can be expected to be influenced by ship emissions. In contrast, ship traffic and thus emissions from shipping are low for all other measurement sites shown in Fig. 3 (Tahiti, Midway Island, Amsterdam Island).

E5/M1-MADE underestimates AOT compared to Aeronet observations for the sites Tahiti, Kaashidoo, Male, and Capo Verde. The sites Kaashidoo and Male in the Indian Ocean are located near the Indian subcontinent. Thus, we expect the AOT measured at these sites to be influenced by continental outflow of polluted air from India, which does not seem to be reproduced by the model properly. In addition, the 2000 emission data used in the model study might be too low due to the fast economic growth in these regions and thus 
Pacific Ocean

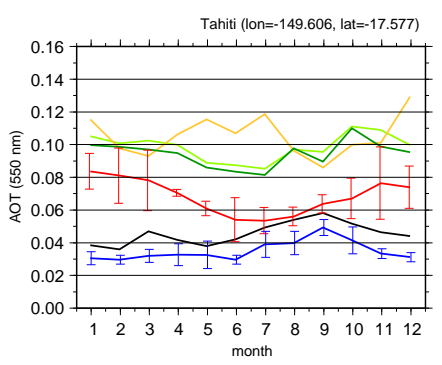

Coconut_Island (lon=-157.79, lat=21.433)
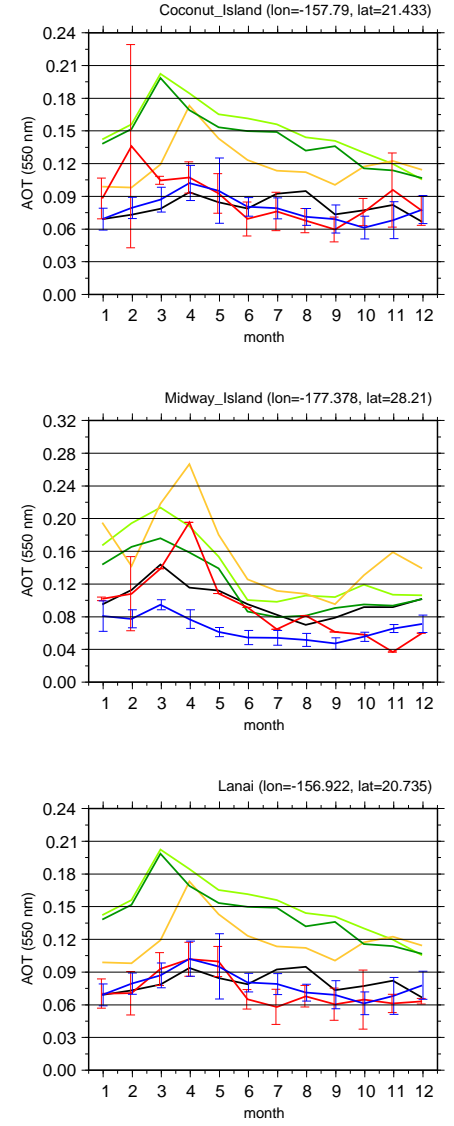

Indian Ocean

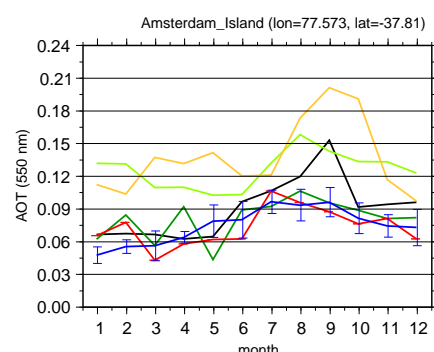

month
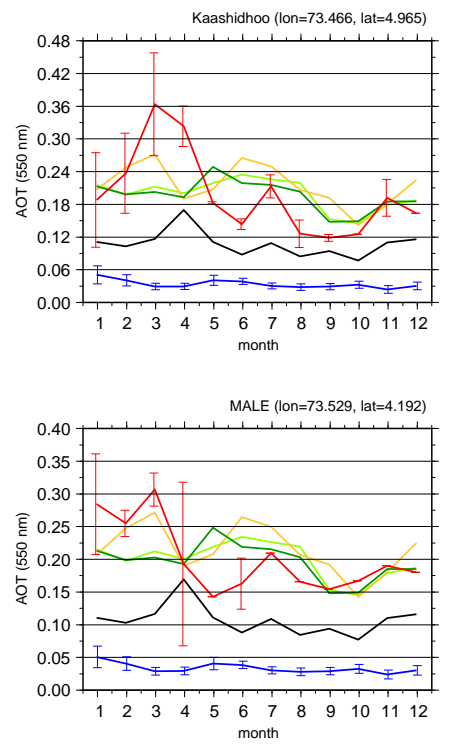

Atlantic Ocean
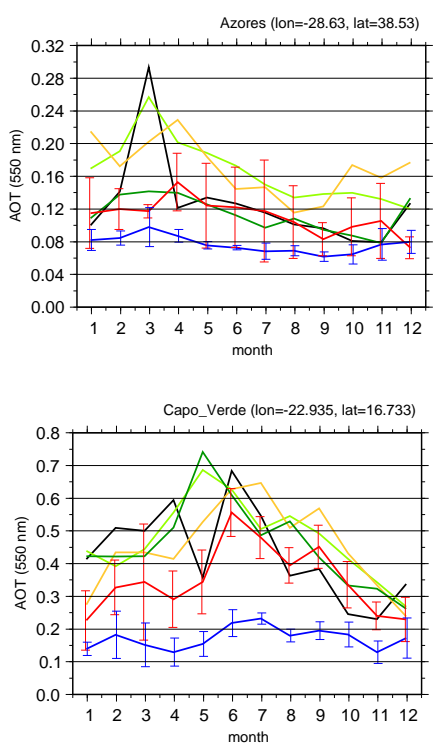

month

— satellite composite (MODIS, AVHRR, TOMS) MODIS (2000-2003) - MISR (2000-2005)

—_ ECHAM5/MESSy1-MADE (1999-2004) - Aeronet (1999-2004)

Fig. 3. Multi-year average seasonal cycle of the aerosol optical thickness at $550 \mathrm{~nm}$ calculated by ECHAM5/MESSy1-MADE (blue), measured by ground based Aeronet stations (red; Holben et al., 1998), MODIS (light green; Kaufman et al., 1997; Tanre et al., 1997) and MISR (yellow; Kahn et al., 1998; Martonchik et al., 1998) satellite data. The AeroCom model ensemble median (black) and a satellite composite of MODIS, AVHRR and TOMS data (dark green) as discussed by Kinne et al. (2006) are also shown. The map depicts the geographical locations of the Aeronet stations (red circles) and the number of ships larger than 1000 gross tons per $1^{\circ} \times 1^{\circ}$ box per year reported by AMVER for the year 2001 (Endresen et al., 2003). For details see text.

resulting in an underestimation by the model. The measurement site Capo Verde in the Atlantic Ocean is located off the west coast of Africa in a latitude region characterized by easterly trade winds transporting mineral dust from the deserts out onto the Atlantic Ocean. Comparisons of AOT with measurements from other regions with a high contribution of mineral dust to the total AOT indicate that E5/M1-MADE generally underestimates AOT from this aerosol component. As mineral dust is not emitted by international shipping, for the purpose of this study the detected differences between model and measurements are acceptable. However, this clearly points to the need for future improvements of the representation of mineral dust in the model. 


\subsection{Total cloud cover}

The multi-year zonal averages of total cloud cover calculated by E5/M1-MADE and obtained from ISCCP (International Satellite Cloud Climatology Project) satellite observations (Rossow et al., 1996) from 1983 to 2004 are shown in Fig. 4. The total cloud cover in the latitude range $60^{\circ} \mathrm{S}$ to $60^{\circ} \mathrm{N}$ where most ship traffic takes place is well reproduced by the model. The difference between model and satellite data is below $5 \%$ for most latitudes. In the polar regions, E5/M1-MADE overestimates the total cloud cover by up to $20-25 \%$ near $90^{\circ} \mathrm{S}$ and by up to about $15 \%$ near $90^{\circ} \mathrm{N}$. The inter-annual variability of the zonally averaged total cloud cover is only small, with the $1-\sigma$ standard deviation mostly below $1 \%$. On global annual average, the simulated total cloud cover of $68 \%$ differs insignificantly from the observed total cloud cover from ISCCP of $66 \%$.

3.4 Cloud droplet number concentration (CDNC) and effective cloud droplet radii

In a recent study, satellite observations from MODIS and AMSR-E have been used to derive cloud droplet number concentrations from cloud effective radii and optical thickness for marine boundary layer clouds (Bennartz, 2007). The MODIS data cover the period July 2002 to December 2004. The oceanic regions we analyze here include the Pacific west of North America $\left(155^{\circ} \mathrm{W}-105^{\circ} \mathrm{W}, 18^{\circ} \mathrm{N}-39^{\circ} \mathrm{N}\right)$, the Pacific west of South America $\left(100^{\circ} \mathrm{W}-60^{\circ} \mathrm{W}, 37^{\circ} \mathrm{S}-8^{\circ} \mathrm{S}\right)$, the Atlantic west of North Africa $\left(45^{\circ} \mathrm{W}-10^{\circ} \mathrm{W}, 15^{\circ} \mathrm{N}-45^{\circ} \mathrm{N}\right)$, the Atlantic west of Southern Africa $\left(20^{\circ} \mathrm{W}-20^{\circ} \mathrm{E}, 34^{\circ} \mathrm{S}-\right.$ $\left.0^{\circ}\right)$, and the Pacific east of Northeast Asia $\left(110^{\circ} \mathrm{E}-170^{\circ} \mathrm{E}\right.$, $16^{\circ} \mathrm{N}-35^{\circ} \mathrm{N}$ ).

The cloud droplet number concentrations and effective cloud droplet radii simulated by the model are calculated from the annual mean of all grid cells in the regions specified above, that are defined as ocean according to the T42 land-/sea-mask of E5/M1-MADE. The altitude range of the model data covers $0.6-1.1 \mathrm{~km}$. Figure 5 shows the geographical distributions of cloud droplet number concentration and cloud droplet effective radius over the ocean calculated by the model, which are used for intercomparison with the satellite data. Table 2 summarizes the model results using ship emission inventories A, B and C, as well as the model simulation without ship emissions and the satellite data from MODIS and AMSR-E for average cloud droplet number concentrations $N$ and cloud droplet effective radii $r$. Error estimates for the cloud droplet number concentrations from the satellite data depend particularly on cloud fraction and liquid water path. For cloud fractions above 0.8 the relative retrieval error in cloud droplet number concentration is smaller than $80 \%$, for small cloud fractions $(<0.1)$, the errors in $N$ can be up to $260 \%$ (Bennartz, 2007).

Basically, the model and satellite data show good agreement in cloud droplet number concentration. The model data

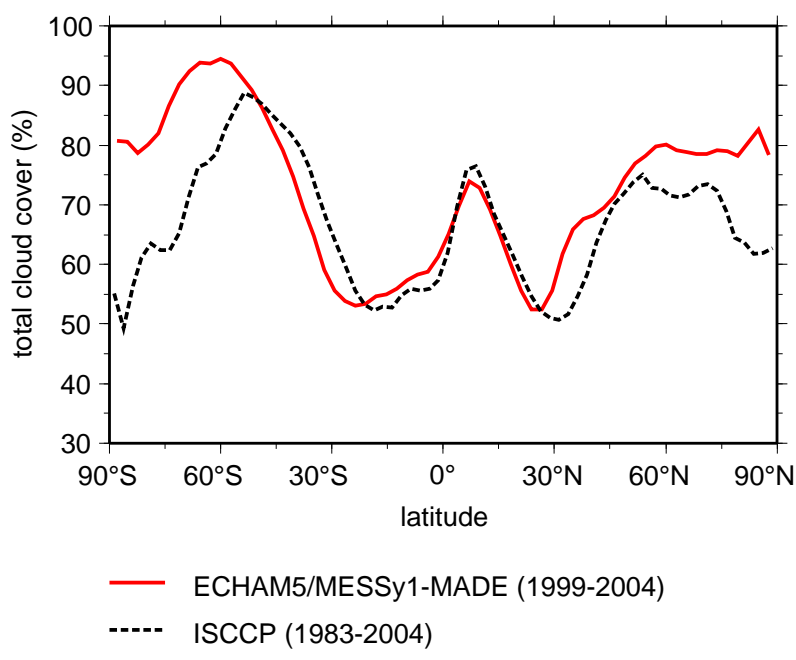

Fig. 4. Multi-year zonal average of the total cloud cover calculated by ECHAM5/MESSy1-MADE (solid) and obtained from ISCCP (International Satellite Cloud Climatology Project) satellite data for the period 1983-2004 (dashed; Rossow et al., 1996) in \%.

lie mostly within the observed range spanned by the standard deviation and the results obtained from the satellite data applying an alternative parameterization to retrieve the cloud droplet number concentration from measured effective radii and cloud optical thickness (Table 2). Bennartz (2007) concluded that marine boundary layer clouds even over the remote oceans have higher cloud droplet number concentrations in the Northern Hemisphere than in the Southern Hemisphere. This basic feature is reproduced by the model showing higher cloud droplet number concentrations over the $\mathrm{Pa}$ cific west of North America $\left(118-127 \mathrm{~cm}^{-3}\right)$ than over the Pacific west of South America $\left(98-100 \mathrm{~cm}^{-3}\right)$ as well as over the Atlantic west of North Africa $\left(118-133 \mathrm{~cm}^{-3}\right)$ than over the Atlantic west of Southern Africa $\left(114-121 \mathrm{~cm}^{-3}\right)$. Whereas the simulated cloud droplet number concentrations are in the upper range of the numbers given by the satellite data for all these oceanic regions, the simulated cloud droplet number concentrations are lower than observed over the Pacific east of Northeast Asia. This might indicate an underestimation of Asian aerosol and precursor emissions in the model, which is consistent with the findings in Sect. 3.2 for the Aeronet measurement sites Kaashidoo and Male in the Indian Ocean.

The effective cloud droplet radii derived from the satellite data lie between $11 \mu \mathrm{m}$ to $13 \mu \mathrm{m}$. Here the model gives slightly smaller values ranging from $10 \mu \mathrm{m}$ to $11 \mu \mathrm{m}$ for the regions North America, North Africa, South America, and Southern Africa. For the region Northeast Asia, the average effective radii calculated by the model range from $8 \mu \mathrm{m}$ to $9 \mu \mathrm{m}$, whereas the satellite data suggest 11 to $12 \mu \mathrm{m}$. Smaller cloud droplet radii and smaller cloud droplet number concentrations indicate an underestimation of the liquid 
Table 2. Annual average values for cloud droplet number concentrations $N$ in $\mathrm{cm}^{-3}$ and cloud droplet effective radii $r$ in $\mu \mathrm{m}$ calculated by ECHAM5/MESSy1-MADE for low marine clouds $(0.6-1.1 \mathrm{~km}$ ) and derived from satellite data (Bennartz, 2007). Mean values with standard deviation are presented. The values in parentheses correspond to estimates derived from the satellite data using an alternative parameterization.

\begin{tabular}{|c|c|c|c|c|c|}
\hline Region & Inventory A & Inventory B & Inventory $\mathrm{C}$ & $\begin{array}{l}\text { No ship } \\
\text { emissions }\end{array}$ & Satellite data \\
\hline $\begin{array}{l}\text { North America } \\
\left(155^{\circ} \mathrm{W}-105^{\circ} \mathrm{W},\right. \\
\left.18^{\circ} \mathrm{N}-39^{\circ} \mathrm{N}\right)\end{array}$ & $\begin{array}{l}\mathrm{N}=125 \\
\mathrm{r}=10.61\end{array}$ & $\begin{array}{l}\mathrm{N}=119 \\
\mathrm{r}=10.68\end{array}$ & $\begin{array}{l}\mathrm{N}=127 \\
\mathrm{r}=10.57\end{array}$ & $\begin{array}{l}\mathrm{N}=118 \\
\mathrm{r}=10.73\end{array}$ & $\begin{array}{l}\mathrm{N}=96(104) \pm 26 \\
\mathrm{r}=11.99(12.07)\end{array}$ \\
\hline $\begin{array}{l}\text { North Africa } \\
\left(45^{\circ} \mathrm{W}-10^{\circ} \mathrm{W},\right. \\
\left.15^{\circ} \mathrm{N}-45^{\circ} \mathrm{N}\right)\end{array}$ & $\begin{array}{l}\mathrm{N}=133 \\
\mathrm{r}=10.20\end{array}$ & $\begin{array}{l}\mathrm{N}=129 \\
\mathrm{r}=10.24\end{array}$ & $\begin{array}{l}\mathrm{N}=130 \\
\mathrm{r}=10.22\end{array}$ & $\begin{array}{l}\mathrm{N}=118 \\
\mathrm{r}=10.39\end{array}$ & $\begin{array}{l}\mathrm{N}=95(103) \pm 23 \\
\mathrm{r}=11.42(12.05)\end{array}$ \\
\hline $\begin{array}{l}\text { South America } \\
\left(100^{\circ} \mathrm{W}-60^{\circ} \mathrm{W} \text {, }\right. \\
\left.37^{\circ} \mathrm{S}-8^{\circ} \mathrm{S}\right)\end{array}$ & $\begin{array}{l}\mathrm{N}=100 \\
\mathrm{r}=11.71\end{array}$ & $\begin{array}{l}\mathrm{N}=98 \\
\mathrm{r}=11.70\end{array}$ & $\begin{array}{l}\mathrm{N}=98 \\
\mathrm{r}=11.71\end{array}$ & $\begin{array}{l}\mathrm{N}=98 \\
\mathrm{r}=11.70\end{array}$ & $\begin{array}{l}\mathrm{N}=77(84) \pm 36 \\
\mathrm{r}=12.97(12.77)\end{array}$ \\
\hline $\begin{array}{l}\text { South Africa } \\
\left(20^{\circ} \mathrm{W}-20^{\circ} \mathrm{E},\right. \\
\left.34^{\circ} \mathrm{S}-0^{\circ}\right)\end{array}$ & $\begin{array}{l}\mathrm{N}=121 \\
\mathrm{r}=11.76\end{array}$ & $\begin{array}{l}\mathrm{N}=116 \\
\mathrm{r}=11.81\end{array}$ & $\begin{array}{l}\mathrm{N}=116 \\
\mathrm{r}=11.79\end{array}$ & $\begin{array}{l}\mathrm{N}=114 \\
\mathrm{r}=11.82\end{array}$ & $\begin{array}{l}\mathrm{N}=95(103) \pm 19 \\
\mathrm{r}=11.82(12.80)\end{array}$ \\
\hline $\begin{array}{l}\text { Northeast Asia } \\
\left(110^{\circ} \mathrm{E}-170^{\circ} \mathrm{E} \text {, }\right. \\
\left.16^{\circ} \mathrm{N}-35^{\circ} \mathrm{N}\right)\end{array}$ & $\begin{array}{l}\mathrm{N}=118 \\
\mathrm{r}=8.56\end{array}$ & $\begin{array}{l}\mathrm{N}=115 \\
\mathrm{r}=8.58\end{array}$ & $\begin{array}{l}\mathrm{N}=118 \\
\mathrm{r}=8.56\end{array}$ & $\begin{array}{l}\mathrm{N}=114 \\
\mathrm{r}=8.59\end{array}$ & $\begin{array}{l}\mathrm{N}=129(135) \pm 23 \\
\mathrm{r}=11.25(11.8)\end{array}$ \\
\hline
\end{tabular}
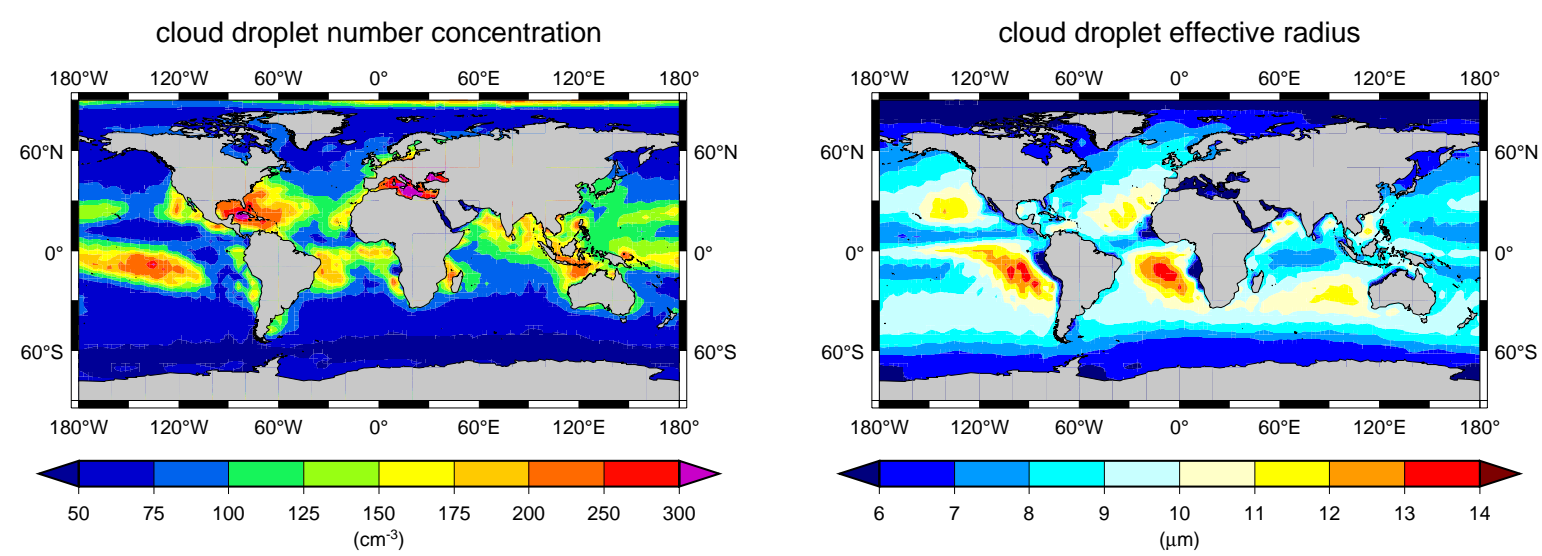

Fig. 5. Multi-year average of the cloud droplet number concentration in $\mathrm{cm}^{-3}$ (left) and cloud droplet effective radius in $\mu \mathrm{m}$ (right) over the ocean calculated by ECHAM5/MESSy1-MADE without ship emissions for model level $16(0.6-1.1 \mathrm{~km})$.

water content of low maritime clouds by the model in this region.

\subsection{Cloud forcing}

The cloud forcing is calculated as the difference between all-sky and clear-sky outgoing radiation at the top of the atmosphere (ToA) in the solar spectral range (shortwave cloud forcing) and in the thermal spectral range (longwave cloud forcing). The cloud forcing quantifies the impact of clouds on the radiation budget (negative or positive cloud forcings correspond to an energy loss and a cooling effect or an energy gain and warming effect, respectively). Fig- ure 6 shows the zonally averaged annual mean short- and longwave cloud forcings calculated by E5/M1-MADE and obtained from ERBE (Earth Radiation Budget Experiment) satellite observations (Barkstrom, 1984) for the period 19851989. E5/M1-MADE is able to reproduce the observed shortwave cloud forcing reasonably well, i.e. the model results lie mostly within the uncertainty range of the ERBE measurements which is estimated to be about $5 \mathrm{~W} / \mathrm{m}^{2}$. However, the model tends to overestimate the observed values (absolute values) in particular near the two local maxima of the shortwave cloud forcing at about $20^{\circ} \mathrm{N}$ and $20^{\circ} \mathrm{S}$. Here, deviations between model and satellite data reach up to $10 \mathrm{~W} / \mathrm{m}^{2}$. This overestimation could be caused by the too small radii in 
solar spectral range

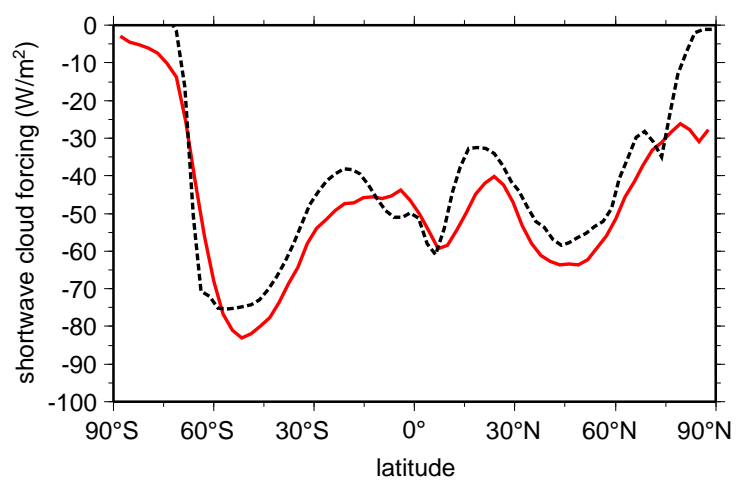

thermal spectral range

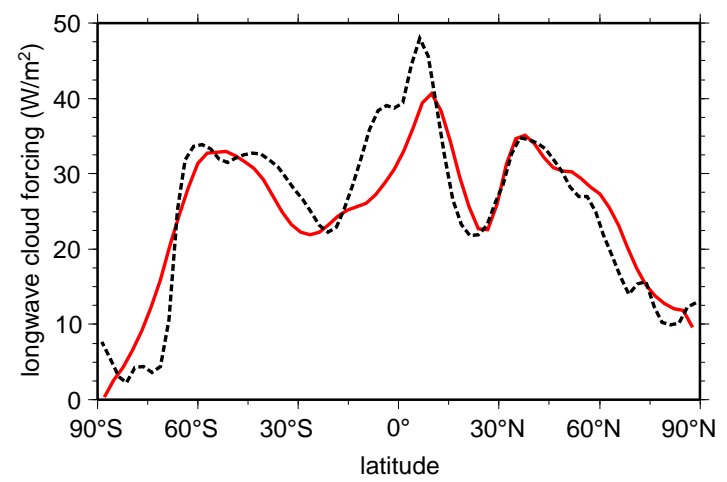

ERBE (1985-1989)

ECHAM5/MESSy1-MADE (1999-2004)

Fig. 6. Multi-year zonal average of the top of the atmosphere (ToA) cloud forcing calculated by ECHAM5/MESSy1-MADE (solid) and obtained from ERBE (Earth Radiation Budget Experiment) satellite observations for the period 1985-1989 (dashed; Barkstrom, 1984). The left panel shows the cloud forcing in the solar spectral range (shortwave cloud forcing), the right panel in the thermal spectral range (longwave cloud forcing) in $\mathrm{W} \mathrm{m}^{-2}$.

marine stratocumuli as discussed in Sect. 3.4. It also affects the global annual averages. The model calculates a shortwave cloud forcing of $-52.9 \mathrm{~W} / \mathrm{m}^{2}$, the ERBE satellite data suggest a value of $-47.4 \mathrm{~W} / \mathrm{m}^{2}$.

The longwave cloud forcing calculated by E5/M1-MADE is in fairly good agreement with the ERBE observations, too. Differences between model and satellite data are below $5 \mathrm{~W} / \mathrm{m}^{2}$ at most latitudes. The global annual averages of the longwave cloud forcing are $+28.0 \mathrm{~W} / \mathrm{m}^{2}$ (E5/M1-MADE) and $+29.3 \mathrm{~W} / \mathrm{m}^{2}$ (ERBE). However, the maximum shown in the satellite data near the equator is not reproduced to its full extent by the model indicative of either insufficient high clouds or an underestimation of their altitude. Maximum deviations between model and satellite data of up to $12 \mathrm{~W} / \mathrm{m}^{2}$ are found in this region.

\section{Results}

\subsection{Contribution of shipping to the global aerosol}

The dominant aerosol component resulting from ship emissions is sulfate, which is formed by the oxidation of $\mathrm{SO}_{2}$ by the hydroxyl radical $(\mathrm{OH})$ in the gas phase or by $\mathrm{O}_{3}$ and hydrogen peroxide $\left(\mathrm{H}_{2} \mathrm{O}_{2}\right)$ in the aqueous phase of cloud droplets. Depending on the ship emission inventory used, $2.3 \%(\mathrm{~B}, \mathrm{C})$ to $3.6 \%(\mathrm{~A})$ of the total annual sulfate burden stems from shipping (Table 3). On average, 30-40\% of the simulated sulfate mass concentration related to small particles $(<1 \mu \mathrm{m})$ near the surface above the main shipping routes originates from shipping (Fig. 7). In contrast, contributions are smaller for black carbon emissions from shipping $(0.4 \%$ in $A$ to $1.4 \%$ in $B)$ and particulate organic matter $(0.1 \%$ in A to $1.1 \%$ in $\mathrm{C}$ ), because the ship emission totals of both compounds are small compared to the contributions of fossil fuel combustion over the continents or to biomass burning. Despite high $\mathrm{NO}_{\mathrm{x}}$ emissions from shipping, the global aerosol nitrate burden is only slightly increased by $0.1-0.2 \%$ using inventory $\mathrm{A}$ and $\mathrm{B}$, but increased by $2.3 \%$ using inventory $\mathrm{C}$. Due to the lower average $\mathrm{SO}_{2}$ emissions in inventory $\mathrm{C}$ compared to inventory $\mathrm{A}$, less ammonium is bound by $\mathrm{SO}_{4}$ and thus more ammonium-nitrate forms. This results in higher aerosol nitrate concentrations. Using inventory $\mathrm{B}$, aerosol nitrate is lower than using inventory $\mathrm{C}$ despite low $\mathrm{SO}_{2}$ emissions. This is caused by the low $\mathrm{NO}_{\mathrm{x}}$ emissions in inventory $\mathrm{B}$ compared to inventory $\mathrm{C}$ (Table 1 ). The increase in the water soluble compounds sulfate, nitrate and associated ammonium causes an increase in the global burden of aerosol liquid water contained in the optically most active particles in the sub-micrometer size-range. This liquid water increase amounts to $4.3 \%(\mathrm{~A}), 2.2 \%(\mathrm{~B})$, and $3.5 \%(\mathrm{C})$. Table 3 summarizes the total burdens and the relative contribution of shipping for the aerosol compounds considered in E5/M1-MADE for all three ship emission inventories.

The model calculates a ship induced increase in the particle number concentration of the Aitken mode particles (typically smaller than $0.1 \mu \mathrm{m}$ ) of about $40 \%$ near the surface above the main shipping region in the Atlantic Ocean. Furthermore, the average geometric mean diameter of these particles decreases from $0.05 \mu \mathrm{m}$ to $0.04 \mu \mathrm{m}$ as the freshly emitted particles from shipping are smaller than the aged Aitken particles typically found above the oceans far away from any continental source. Subsequent processes such as condensation of sulfuric acid vapor enable some particles to grow 


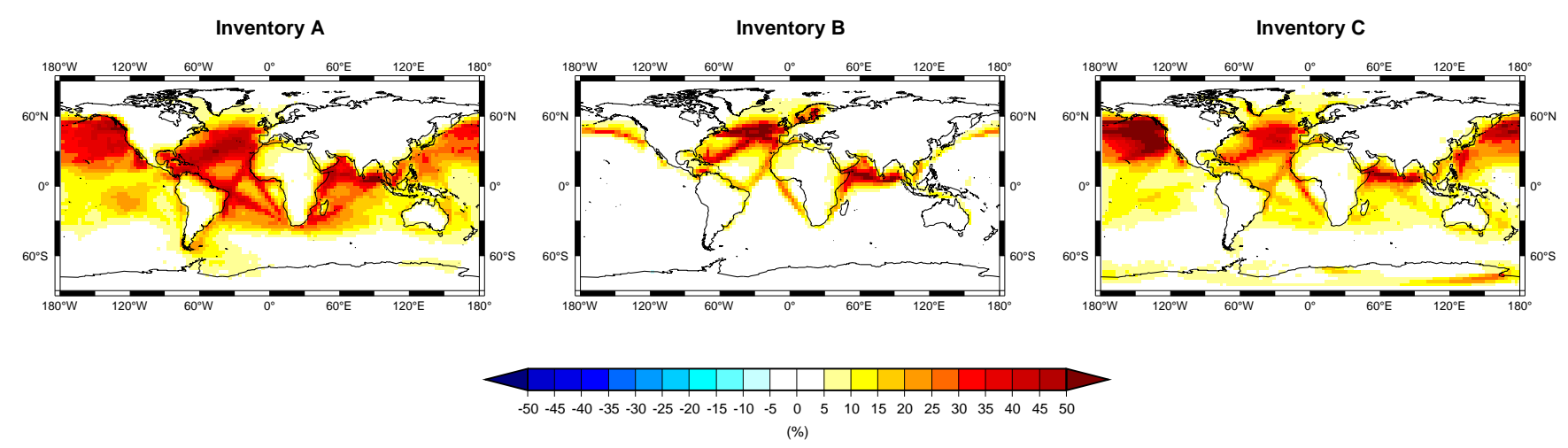

Fig. 7. Simulated relative changes (annual mean) in $\%$ of near surface sulfate mass concentration in fine particles $(<1 \mu \mathrm{m})$ due to shipping. Left: ship emissions from inventory A (Eyring et al., 2005a), middle: inventory B (Dentener et al., 2006), right: inventory C (Wang et al., $\left.2007^{1}\right)$.

Table 3. Global burden of aerosol compounds considered in ECHAM5/MESSy1-MADE and the contribution from international shipping in the model simulations using the three emission inventories A (Eyring et al., 2005a), B (Dentener et al., 2006), and C (Wang et al., 2007 ${ }^{1}$ ).

\begin{tabular}{lcccccc}
\hline & \multicolumn{2}{c}{ Inventory A } & \multicolumn{2}{c}{ Inventory B } & \multicolumn{2}{c}{ Inventory C } \\
\cline { 2 - 7 } Compound & $\begin{array}{c}\text { Atmospheric } \\
\text { Burden } \\
(\mathrm{Tg})\end{array}$ & $\begin{array}{c}\text { Contribution } \\
\text { of Shipping } \\
(\%)\end{array}$ & $\begin{array}{c}\text { Atmospheric } \\
\text { Burden } \\
(\mathrm{Tg})\end{array}$ & $\begin{array}{c}\text { Contribution } \\
\text { of Shipping } \\
(\%)\end{array}$ & $\begin{array}{c}\text { Atmospheric } \\
\text { Burden } \\
(\mathrm{Tg})\end{array}$ & $\begin{array}{c}\text { Contribution } \\
\text { of Shipping } \\
(\%)\end{array}$ \\
\hline $\mathrm{SO}_{4}$ & 1.531 & 3.6 & 1.511 & 2.3 & 1.511 & 2.3 \\
$\mathrm{NH}_{4}$ & 0.366 & 1.4 & 0.365 & 0.9 & 0.365 & 0.9 \\
$\mathrm{NO}_{3}$ & 0.146 & 0.2 & 0.146 & 0.1 & 0.150 & 2.3 \\
$\mathrm{H}_{2} \mathrm{O}$ & 17.881 & 1.0 & 17.784 & 0.4 & 17.841 & 0.6 \\
$\mathrm{BC}$ & 0.119 & 0.4 & 0.122 & 1.4 & 0.119 & 0.8 \\
$\mathrm{POM}$ & 1.040 & 0.1 & 1.047 & 0.1 & 1.050 & 1.1 \\
Sea Salt & 3.588 & - & 3.582 & - & 3.589 & - \\
Mineral Dust & 9.042 & - & 9.045 & - & 9.044 & - \\
\hline
\end{tabular}

into the next larger size-range, the accumulation mode $(0.1$ to $1 \mu \mathrm{m})$, increasing the number concentration in this mode. Accumulation mode particles act as efficient condensation nuclei for cloud formation. The model results indicate that the accumulation mode particle number concentration in the lowermost boundary layer above the main shipping routes in the Atlantic Ocean is increased by about $15 \%$. In contrast to the Aitken mode, the average modal mean diameter of the simulated accumulation mode is not affected by ship emissions and remains almost constant.

The changes in particle number concentration, particle composition and size-distribution result in an increase in aerosol optical thickness above the oceans of typically 2-3\% (Fig. 8, upper row). Depending on the inventory used, different amounts of emissions are assigned to specific regions. This leads to differences in the results: Individual regions such as the Gulf of Mexico show increases by up to $8-10 \%$ (A), the Northeastern Pacific by up to $6 \%$ (C), and the highly frequented shipping route through the Red Sea (Suez Canal) to the tip of India in the Indian Ocean by up to $10-14 \%$ (A,
$\mathrm{B}, \mathrm{C})$. This effect is mainly related to enhanced scattering of solar radiation by sulfate, nitrate, ammonium, and associated aerosol liquid water. The calculated changes in the global annual average clear-sky top of the atmosphere (ToA) solar radiative flux are $-0.038 \mathrm{~W} / \mathrm{m}^{2}(\mathrm{~A}),-0.014 \mathrm{~W} / \mathrm{m}^{2}(\mathrm{~B})$, and $-0.029 \mathrm{~W} / \mathrm{m}^{2}$ (C) (Table 4). Local changes of up to $-0.25 \mathrm{~W} / \mathrm{m}^{2}$ are simulated for the Gulf of Mexico (A), the Northeastern Pacific (C), or the highly frequented regions of the Indian Ocean (A, B, C). These regions can also be identified in the zonal averages (Fig. 8, lower row). The contribution to changes in the clear-sky ToA thermal flux due to shipping is negligible and not statistically significant compared to its statistical fluctuations.

The changes in the simulated clear-sky fluxes do not represent the global average direct aerosol forcing because the presence of clouds strongly modifies the aerosol impact on the radiation field. Small changes in cloud properties such as liquid water content, cloud droplet effective radius, or cloud cover between the model experiments with and without ship emissions are introduced not only because meteorology of 
Table 4. Annual average changes in the top of the atmosphere (ToA) shortwave radiation flux (solar spectral range) due to direct aerosol forcing (all-sky) from shipping in $\mathrm{W} \mathrm{m}^{-2}$. The values in parentheses are the corresponding changes in the ToA shortwave clear-sky radiation flux.

\begin{tabular}{lccc}
\hline $\begin{array}{l}\text { Ship emission } \\
\text { inventory }\end{array}$ & $\begin{array}{c}\text { Pacific Ocean } \\
\left(120^{\circ} \mathrm{E}-80^{\circ} \mathrm{W},\right. \\
\left.40^{\circ} \mathrm{S}-60^{\circ} \mathrm{N}\right)\end{array}$ & $\begin{array}{c}\text { Atlantic Ocean } \\
\left(75^{\circ} \mathrm{W}-15^{\circ} \mathrm{E},\right. \\
\left.40^{\circ} \mathrm{S}-60^{\circ} \mathrm{N}\right)\end{array}$ & $\begin{array}{c}\text { Global } \\
\text { mean }\end{array}$ \\
\hline $\mathrm{A}$ & $-0.033(-0.072)$ & $-0.058(-0.080)$ & $-0.011(-0.038)$ \\
$\mathrm{B}$ & $-0.016(-0.038)$ & $-0.028(-0.045)$ & $-0.011(-0.014)$ \\
$\mathrm{C}$ & $-0.024(-0.048)$ & $-0.040(-0.054)$ & $-0.013(-0.029)$ \\
\hline
\end{tabular}
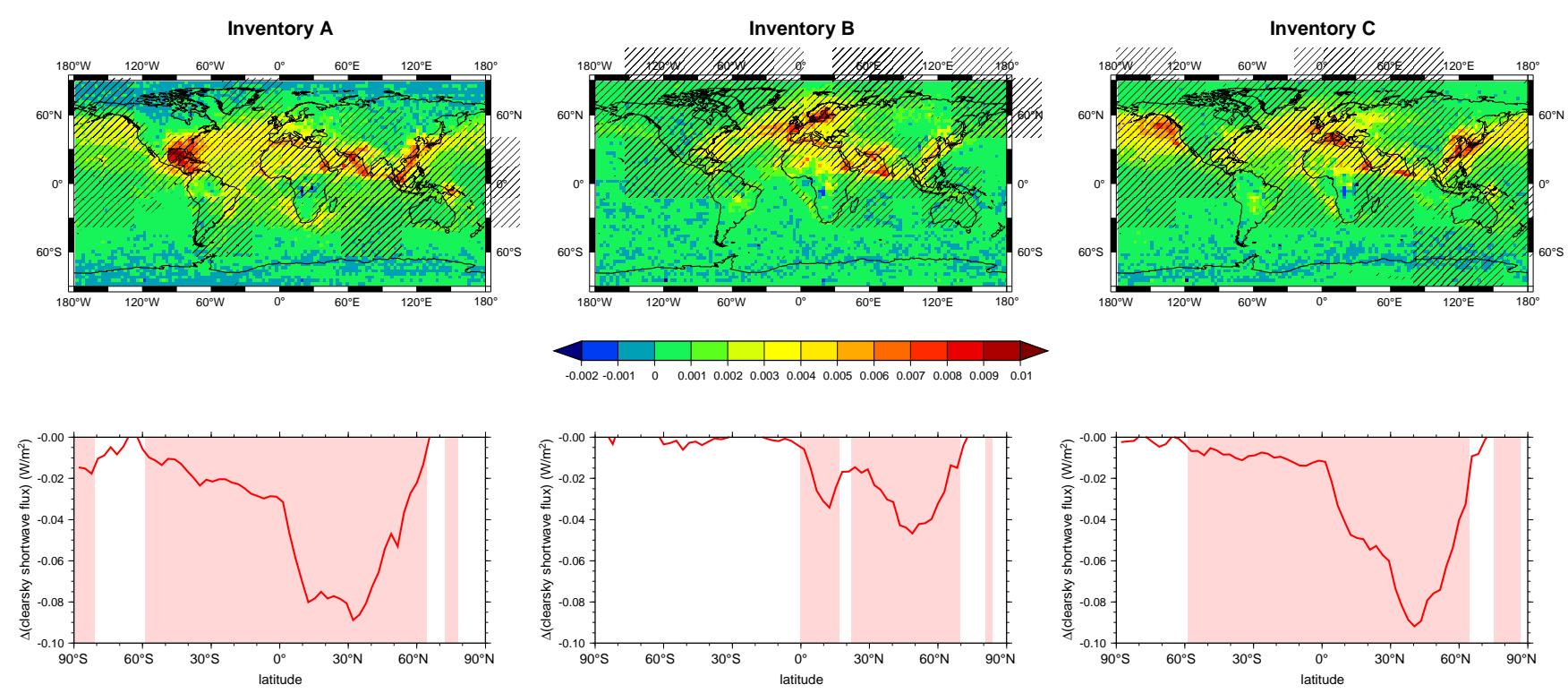

Fig. 8. Climatological annual mean (1999-2004) of changes in total aerosol optical thickness at 550 nm due to shipping (upper row) and corresponding changes in the zonal mean shortwave clear-sky radiation flux at the top of the atmosphere (ToA) in $\mathrm{W} \mathrm{m}^{-2}$ (lower row). Hatched areas (upper row) and light-red shaded areas (lower row) show differences which are significant compared to the inter-annual variability.

each GCM simulation is not completely identical (random), but also because of modifications of cloud microphysical properties by ship emissions (systematic). These differences in cloud properties change the cloudy-sky ToA shortwave radiation even for identical aerosols. Thus, the calculated all-sky direct aerosol forcing results not only from changes in aerosol properties due to shipping, but also from different cloud properties. This prevents full separation of the direct and indirect effect, which makes a comparison of the direct aerosol effect calculated for the different ship emission inventories difficult. The all-sky direct aerosol forcing in each model simulation is calculated from the differences in the ToA all-sky solar radiation fluxes obtained with and without aerosols by calling the radiation module of the GCM twice. According to our model results, we estimate the direct aerosol forcing from shipping to amount $-0.011 \mathrm{~W} / \mathrm{m}^{2}$ $(\mathrm{A}, \mathrm{B})$ to $-0.013 \mathrm{~W} / \mathrm{m}^{2}$ (C). The differences in the direct aerosol forcing (all-sky) between the three ship emission inventories are smaller than expected from the emission totals (Table 1). This clearly indicates that the geographic distribution of the emissions plays a key role for the impact of ship emissions on the radition budget. Table 4 summarizes the direct aerosol forcing from shipping calculated for the three emission inventories.

\subsection{Modification of cloud microphysical properties}

The second important effect of the aerosol changes due to ship emissions is a modification of cloud microphysical properties. The model simulations reveal that this effect is mainly confined to the lower troposphere from the surface up to about $1.5 \mathrm{~km}$. This implies that regions with a frequent high amount of low clouds above the oceans are most susceptible for modifications due to ship emissions. Such regions 


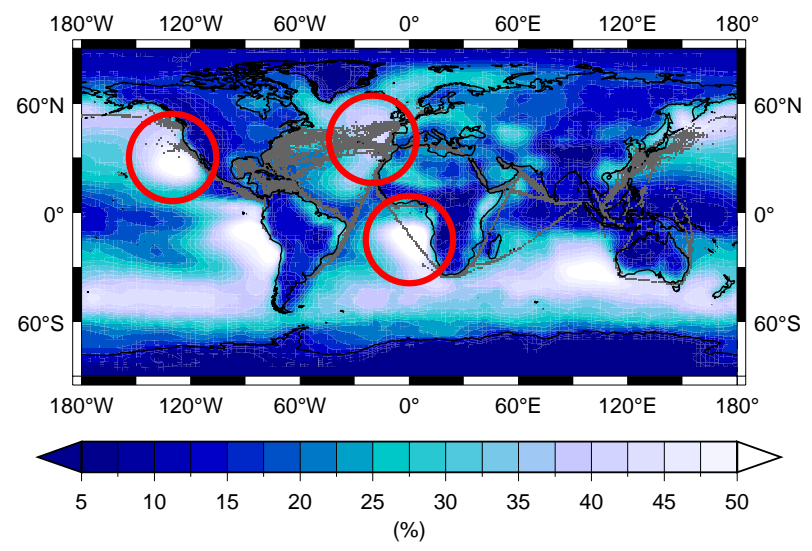

Fig. 9. Annual mean (1983-2004) low cloud amount (\%) derived from ISCCP (International Satellite Cloud Climatology Project) satellite data (Rossow et al., 1996). The highly frequented shipping routes (inventory A) are overlaid in gray. Regions with significant ship traffic (Eyring et al., 2005a) and high amount of low clouds are marked with red circles.

are coinciding with dense ship traffic over the Pacific Ocean west of North America, the Atlantic Ocean west of Southern Africa and the Northeastern Atlantic Ocean (Fig. 9). These regions are consistent with the locations showing the maximum response in the indirect aerosol effect due to shipping calculated by E5/M1-MADE.

Whereas the vertically integrated cloud liquid water content is only slightly (1-2\%) affected by ship emissions and the ice crystal number concentration shows no significant change, simulated cloud droplet number concentrations are significantly increased. Maximum changes of the cloud droplet number are computed above the main shipping routes in the Atlantic and Pacific Ocean at an altitude of about $500 \mathrm{~m}$. These changes in cloud droplet number concentration amount to $30-50 \mathrm{~cm}^{-3}(20-30 \%)$ in the Atlantic (A, B, C) and about $20-40 \mathrm{~cm}^{-3}(15-30 \%, \mathrm{~A}, \mathrm{C})$ and $5-15 \mathrm{~cm}^{-3}$ $(5-10 \%, \mathrm{~B})$ in the Pacific. Table 5 summarizes the annual average changes in cloud droplet number concentration and cloud droplet effective radius for the three ship emission inventories. The corresponding changes in cloud liquid water content at this altitude calculated by the model show an increase in the order of a few percent, but are statistically not significant. The increase in cloud droplet number causes a decrease in the effective radius of the cloud droplets. In the Atlantic Ocean, for instance, the average decrease in the cloud droplet effective radius is $0.42 \mu \mathrm{m}$ (A), $0.17 \mu \mathrm{m}$ (B), and $0.25 \mu \mathrm{m}(\mathrm{C})$ at an altitude of $0.4 \mathrm{~km}$ (see also Table 5). This effect results in an enhanced reflectivity of these low marine clouds. This larger impact on average cloud droplet radii above the Atlantic by ship emissions from inventory A compared to inventories $\mathrm{B}$ and $\mathrm{C}$ cannot be explained by the emission totals only. The emission total of $\mathrm{SO}_{2}$ from inventory A $(5.0 \mathrm{Tg} / \mathrm{yr})$ is similar to that from inventory B
(4.7 Tg/yr). Again, this indicates that the geographic distribution of the emissions plays an important role: Emissions are much more widespread in inventory A compared to B, resulting in a larger impact on the cloud microphysical properties averaged over a larger domain. Figure 10 depicts the annual mean changes in zonal average cloud droplet number concentrations, cloud droplet effective radii, and cloud optical thickness in the spectral range $0.28-0.69 \mu \mathrm{m}$ due to shipping for the three emission inventories. The increase in cloud droplet number concentration and the decrease in cloud droplet effective radii result in an increase in cloud optical thickness of typically 0.1 to 0.3 on zonal annual average. Whereas the changes in cloud optical thickness are limited to the latitude range $0^{\circ}$ to $70^{\circ} \mathrm{N}$ for inventory $\mathrm{B}$, statistically significant changes are calculated between $60^{\circ} \mathrm{S}$ to $60^{\circ} \mathrm{N}$ for inventory A with maximum changes in cloud optical thickness up to about 0.5 in the latitude range around $20^{\circ} \mathrm{N}$ to $30^{\circ} \mathrm{N}$.

The simulated shipping-changes in the annual mean total cloud cover, the geographical precipitation patterns or the total precipitation are statistically not significant compared to the inter-annual variability.

The increased reflectivity of the low marine clouds results in an increased shortwave cloud forcing, calculated as the difference of the all-sky shortwave minus the clear-sky shortwave radiation at the ToA. The shortwave cloud forcing quantifies the impact of clouds on the Earth's radiation budget in the solar spectral range. The changes in the cloud forcing include both, changes in the cloud reflectivity due to altered cloud droplet number concentration (1st indirect effect), as well as changes due to altered precipitation formation efficiency (2nd indirect effect). However, no statistically significant changes in the precipitation patterns or total precipitation have been encountered. Figure 11 shows the geographical distribution of the 6-year annual average changes in ToA shortwave cloud forcing and the corresponding zonal means for the three ship emission inventories A, B, and C. Statistically significant changes in the shortwave cloud forcing are found in particular above the Pacific off the west coast of North America (A, C), the Northeastern Atlantic (A, B, C) and above the Atlantic off the west coast of Southern Africa (A, C). Local changes in the Pacific and Atlantic can reach -3 to $-5 \mathrm{~W} / \mathrm{m}^{2}$ (A, C) and -2 to $-3 \mathrm{~W} / \mathrm{m}^{2}$ (B). In contrast, changes above the Indian Ocean are smaller despite the high ship traffic density. This is due to the low cloud amount susceptible to ship emissions being rather low in this region (Fig. 9). Simulated changes in the longwave cloud forcing (thermal spectral range) are small and statistically not significant because of the comparably low temperature differences between the sea surface temperature and the cloud top height of the low marine clouds. Changes in the zonally averaged annual mean cloud forcing for the solar spectrum due to ship emissions are mostly confined to the latitude range $40^{\circ} \mathrm{S}$ to $50^{\circ} \mathrm{N}(\mathrm{A}), 10^{\circ} \mathrm{N}$ to $50^{\circ} \mathrm{N}(\mathrm{B})$, and $30^{\circ} \mathrm{S}$ to $50^{\circ} \mathrm{N}(\mathrm{C})$. Table 6 summarizes the annual average changes in shortwave 
cloud droplet number concentration
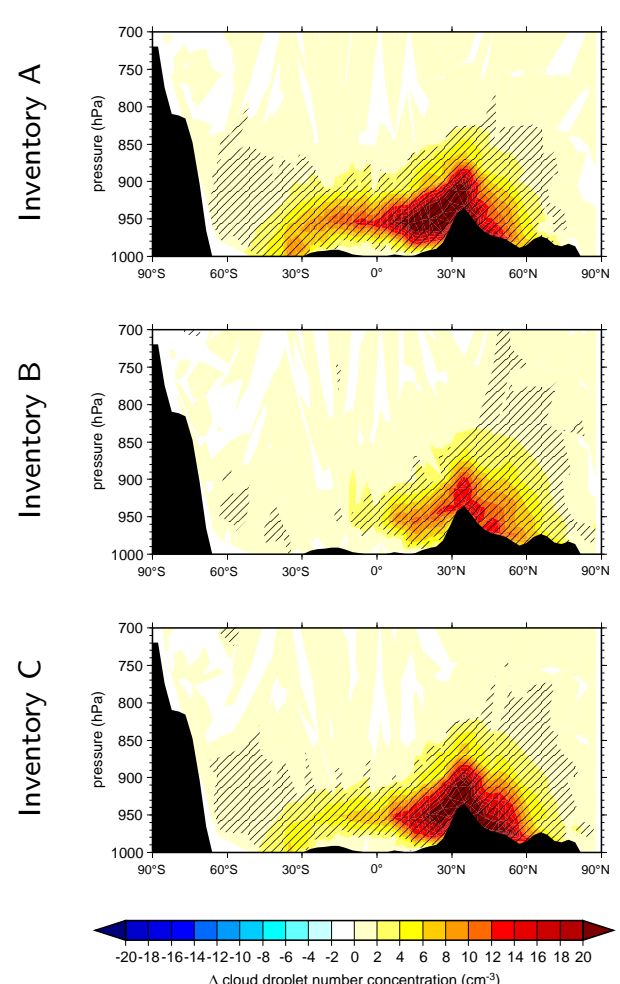

effective cloud droplet radius
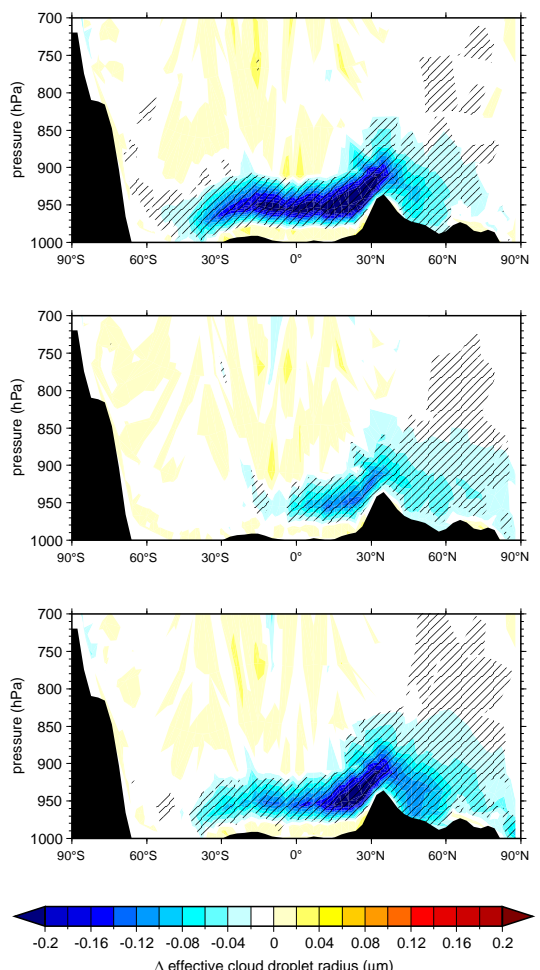

cloud optical thickness
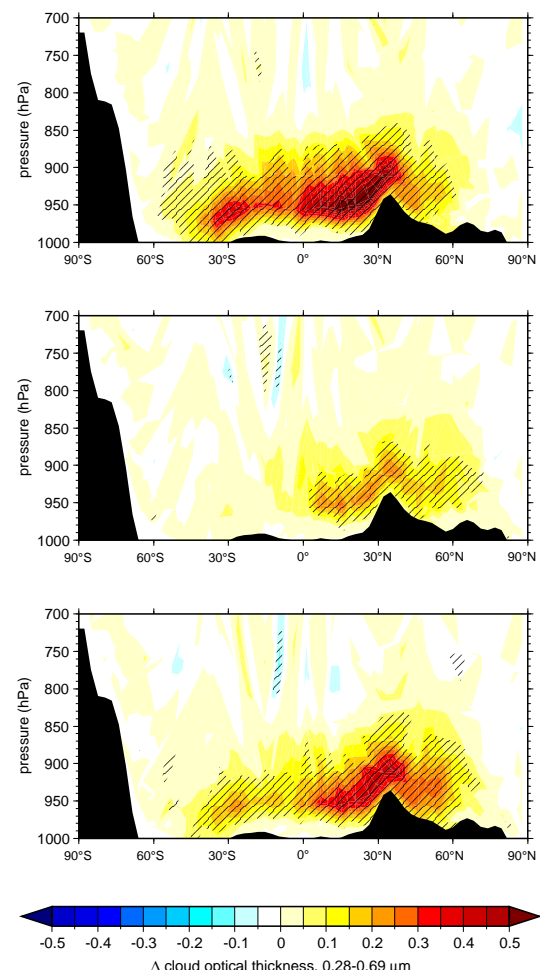

Fig. 10. Climatological annual mean (1999-2004) of zonally averaged changes in cloud droplet number concentrations (left), cloud droplet effective radii (middle), and cloud optical thickness in the spectral range $0.28-0.69 \mu \mathrm{m}$ (right) in the lower troposphere due to shipping. The upper row shows the changes calculated using ship emission inventory A (Eyring et al., 2005a), the middle row depicts changes calculated using ship emission inventory B (Dentener et al., 2006), the lower row shows changes calculated using ship emission inventory C (Wang et al., $2007^{1}$ ). Hatched areas show differences which are significant at the $99 \%$ confidence level compared to their inter-annual variability.

Table 5. Annual average changes in cloud droplet number concentration (CDNC) and cloud droplet effective radius $(r)$ due to shipping. The numbers are given for model level $17(0.3-0.6 \mathrm{~km})$ for which the maximum sensitivity to shipping is simulated. The values in parentheses are given for model level $16(0.6-1.1 \mathrm{~km})$.

\begin{tabular}{lcccccc}
\hline & \multicolumn{2}{c}{ Inventory A } & \multicolumn{2}{c}{ Inventory B } & \multicolumn{2}{c}{ Inventory C } \\
\cline { 2 - 7 } Region & $\begin{array}{c}\Delta(\mathrm{CDNC}) \\
\left(\mathrm{cm}^{-3}\right)\end{array}$ & $\begin{array}{c}\Delta(\mathrm{r}) \\
(\mu \mathrm{m})\end{array}$ & $\begin{array}{c}\Delta(\mathrm{CDNC}) \\
\left(\mathrm{cm}^{-3}\right)\end{array}$ & $\begin{array}{c}\Delta(\mathrm{r}) \\
(\mu \mathrm{m})\end{array}$ & $\begin{array}{c}\Delta(\mathrm{CDNC}) \\
\left(\mathrm{cm}^{-3}\right)\end{array}$ & $\begin{array}{c}\Delta(\mathrm{r}) \\
(\mu \mathrm{m})\end{array}$ \\
\hline $\begin{array}{l}\text { Pacific Ocean } \\
\left(120^{\circ} \mathrm{E}-80^{\circ} \mathrm{W}, 40^{\circ} \mathrm{S}-60^{\circ} \mathrm{N}\right)\end{array}$ & $27.6(6.7)$ & $-0.37(-0.06)$ & $13.7(4.2)$ & $-0.15(-0.03)$ & $18.0(4.4)$ & $-0.23(-0.04)$ \\
$\begin{array}{l}\text { Atlantic Ocean } \\
\left(75^{\circ} \mathrm{W}-15^{\circ} \mathrm{E}, 40^{\circ} \mathrm{S}-60^{\circ} \mathrm{N}\right)\end{array}$ & $30.9(8.2)$ & $-0.42(-0.07)$ & $15.5(5.1)$ & $-0.17(-0.04)$ & $19.9(5.4)$ & $-0.25(-0.06)$ \\
Global mean & $13.6(3.2)$ & $-0.18(-0.02)$ & $5.9(1.8)$ & $-0.06(-0.02)$ & $10.4(2.6)$ & $-0.13(-0.03)$ \\
\hline
\end{tabular}

cloud forcing for all three emission inventories and different regions. The global annual mean changes in the shortwave cloud forcing amount to $-0.60 \mathrm{~W} / \mathrm{m}^{2}(\mathrm{~A}),-0.19 \mathrm{~W} / \mathrm{m}^{2}$ (B), and $-0.44 \mathrm{~W} / \mathrm{m}^{2}(\mathrm{C})$.

A comparison of the results with E5/M1-MADE simulations using pre-industrial emissions for trace gases (van Aardenne et al., 2001) and particles (Dentener et al., 2006) re- sults in a total anthropogenic indirect aerosol effect (including ships) of $-1.1 \mathrm{~W} / \mathrm{m}^{2}$ (B) to $-1.5 \mathrm{~W} / \mathrm{m}^{2}$ (A). These values are within the range of previous model estimates $(-0.9$ to $-2.9 \mathrm{~W} / \mathrm{m}^{2}$ ) (Lohmann and Feichter, 2005) of the total anthropogenic indirect effect. The fourth assessment report of the Intergovernmental Panel on Climate Change (IPCC) reports a best estimate for the cloud albedo effect (1st indirect 

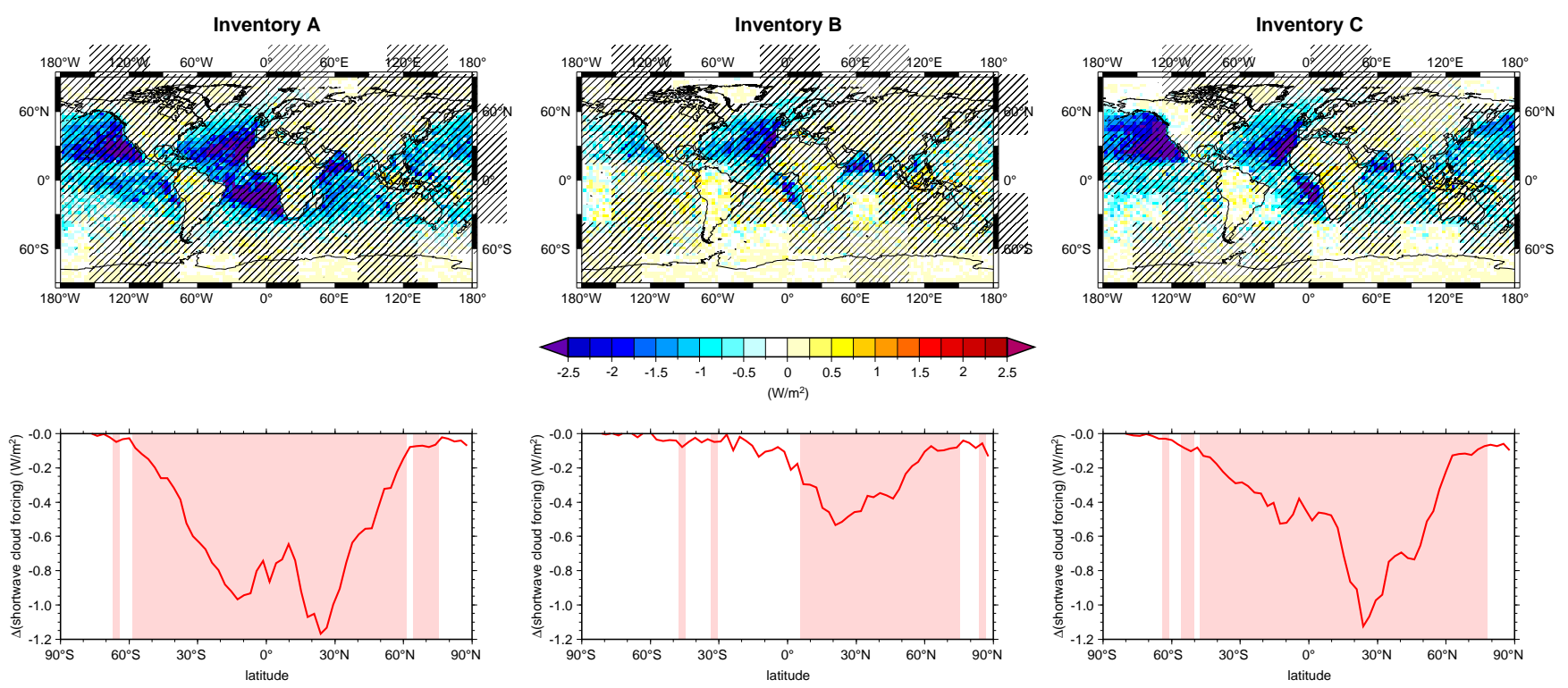

Fig. 11. Multi-year average of simulated changes in shortwave cloud forcing due to shipping at the top of the atmosphere (ToA) in $\mathrm{W} \mathrm{m}^{-2}$. Upper row shows the geographical distribution, lower row zonal averages. Hatched areas (upper row) and light-red shaded areas (lower row) show differences which are significant at the $99 \%$ confidence level compared to the inter-annual variability.

Table 6. Annual average changes in the top of the atmosphere (ToA) shortwave cloud forcing (solar spectral range) due to ship emissions in $\mathrm{W} \mathrm{m}^{-2}$.

\begin{tabular}{lccc}
\hline $\begin{array}{l}\text { Ship emission } \\
\text { inventory }\end{array}$ & $\begin{array}{c}\text { Pacific Ocean } \\
\left(120^{\circ} \mathrm{E}-80^{\circ} \mathrm{W},\right. \\
\left.40^{\circ} \mathrm{S}-60^{\circ} \mathrm{N}\right)\end{array}$ & $\begin{array}{c}\text { Atlantic Ocean } \\
\left(75^{\circ} \mathrm{W}-15^{\circ} \mathrm{E},\right. \\
\left.40^{\circ} \mathrm{S}-60^{\circ} \mathrm{N}\right)\end{array}$ & $\begin{array}{c}\text { Global } \\
\text { mean }\end{array}$ \\
\hline A & -1.22 & -1.46 & -0.60 \\
$\mathrm{~B}$ & -0.46 & -0.60 & -0.19 \\
$\mathrm{C}$ & -0.77 & -0.93 & -0.44 \\
\hline
\end{tabular}

aerosol effect) of $-0.7 \mathrm{~W} / \mathrm{m}^{2}$ with a $5 \%$ to $95 \%$ range of -0.3 to $-1.8 \mathrm{~W} / \mathrm{m}^{2}$ (IPCC, 2007). The results of E5M1$\operatorname{MADE}\left(-1.1\right.$ to $\left.-1.5 \mathrm{~W} / \mathrm{m}^{2}\right)$ are in the upper range of these uncertainties. However, it should be kept in mind, that most models consider ships in a simplified manner such as inventory $\mathrm{B}$ only. Thus, the total indirect forcing using inventory B $\left(-1.1 \mathrm{~W} / \mathrm{m}^{2}\right)$ should be considered only when comparing E5M1-MADE to the IPCC results. According to the results of our model studies, shipping contributes to about $17 \%$ (B) to $39 \%$ (A) of the total anthropogenic indirect effect. This contribution is larger than the contribution of shipping to aerosol emissions, because of larger albedo changes by clouds over dark oceans than over land. In addition, this effect is comparatively large since ship emissions are released in regions with frequent occurrence of low clouds, which are highly susceptible to the enhanced aerosol number concentration in an otherwise clean marine environment. For both reasons, the susceptibility of the radiation budget to ship emissions is much higher than for continental anthropogenic aerosol sources of the same source strength. Simple scaling of the total anthropogenic indirect aerosol effect to the contribution of an individual source to the total atmospheric burden is therefore questionable for shipping.

\subsection{Radiative forcing due to international shipping}

The indirect aerosol effect of shipping on climate discussed in Sect. 4.2 results in a negative radiative forcing (RF) which is, in absolute numbers, much higher than the negative RF caused by the scattering and absorption of solar radiation by aerosol particles (direct aerosol effect) or the positive RF due to greenhouse gases, mainly carbon dioxide and ozone (Fig. 12). $\mathrm{NO}_{\mathrm{x}}$ and other ozone precursor emissions from shipping not only perturb the atmosphere by the formation of $\mathrm{O}_{3}$, but also lead to enhanced levels of $\mathrm{OH}$, increasing removal rates of $\mathrm{CH}_{4}$, thus generating a negative radiative forcing. These previously estimated forcings are all in the range of \pm 15 to $50 \mathrm{~mW} / \mathrm{m}^{2}$ (Endresen et al., 2003; Eyring et al., 2007). RF due to direct $\mathrm{CH}_{4}$ from shipping ( $0.52 \mathrm{Tg}$ $\mathrm{CH}_{4}$ from fuel and tanker loading; Eyring et al., 2005a) has not been estimated so far. However, because of the small contribution $(<0.2 \%)$ to total anthropogenic $\mathrm{CH}_{4}$ emissions (Olivier et al., 2005), the resulting forcings are expected to be negligible compared to the other components. Figure 12 shows the RF due to shipping from $\mathrm{CO}_{2}, \mathrm{O}_{3}, \mathrm{CH}_{4}$, and the direct effect of $\mathrm{SO}_{4}$ particles from Endresen et al. (2003) and Eyring et al. (2007) as well as the radiative forcing due to ship tracks (Schreier et al., 2007) in comparison 
to the estimated direct aerosol effect (Sect. 4.1) and indirect aerosol effect (Sect. 4.2) obtained in this study for the three ship emission inventories A, B, and C. Schreier et al. (2006) showed that ship tracks can change the radiation budget on a local scale, but are short lived and cover a very small fraction of the globe so that their radiative effect on the global scale is negligible $\left(-0.4\right.$ to $-0.6 \mathrm{~mW} / \mathrm{m}^{2} \pm 40 \%$; Schreier et al., 2007). Ship tracks are changes in cloud reflectance due to ship emissions, which are detectable in satellite data and are identified by elongated structures. In contrast, this study investigates particularly the large scale effects of ship emissions on clouds, after for instance $\mathrm{SO}_{2}$ is oxidized to sulfate and emissions are spread out far over the ocean, which are not covered by an investigation of pure ship tracks. The contribution of water vapor emissions from shipping is also negligible. Also shown is a previous estimate by Capaldo et al. (1999), who used a global model without detailed aerosol microphysics and aerosol-cloud interaction and assessed the first indirect effect of $\mathrm{SO}_{4}$ plus organic material particles $\left(-0.11 \mathrm{~W} / \mathrm{m}^{2}\right)$. In contrast to Capaldo et al. (1999), Endresen et al. (2003) and Eyring et al. (2007), the model study presented here considers not only sulfate, but changes in the radiation budget due to the sum of all relevant aerosol components $\left(\mathrm{SO}_{4}, \mathrm{NO}_{3}, \mathrm{NH}_{4}, \mathrm{BC}, \mathrm{POM}\right.$, and aerosol liquid water).

The model results discussed in Sects. 4.1 and 4.2 and shown in Fig. 12 also indicate that the geographical distribution of emissions over the globe plays a key role determining the global impact of shipping. The large differences in the model results obtained with three different ship emission inventories (Eyring et al., 2005a; Dentener et al., 2006, Wang et al., 2007 ${ }^{1}$ ) imply a high uncertainty, but on the other hand the main conclusions of this study hold for all three inventories. For all inventories used, the present-day net RF from ocean-going ships is strongly negative, in contrast to, for instance, estimates of RF from aircraft, ranging from 0.048 to $0.071 \mathrm{~W} / \mathrm{m}^{2}$ (without cirrus) and $0.03 \mathrm{~W} / \mathrm{m}^{2}(0.01$ to $0.08 \mathrm{~W} / \mathrm{m}^{2}$ ) for aviation-induced cirrus (Sausen et al., 2005). In addition, the direct aerosol forcing due to scattering and absorption of solar light by particles from shipping is only of minor importance compared to the indirect aerosol effect. Additional sensitivity simulations with sulfur free fuel with E5/M1-MADE revealed that about $75 \%$ of the direct and indirect aerosol effect from shipping is related to the fuel sulfur content, which is currently about $2.4 \%$ (EPA, 2002). Thus, a simple upscaling of the results from Capaldo et al. (1999) to the total indirect effect considering all relevant aerosol compounds from shipping results in about $-0.15 \mathrm{~W} / \mathrm{m}^{2}$. This value is comparable to the indirect aerosol effect calculated in this study using inventory $\mathrm{B}\left(-0.19 \mathrm{~W} / \mathrm{m}^{2}\right)$. Inventory $\mathrm{B}$ has similar emission totals for $\mathrm{SO}_{2}\left(7.8 \mathrm{Tg} \mathrm{yr}^{-1}\right)$ as the ship emission inventory used by Capaldo et al. (1999) totaling $8.4 \mathrm{Tg} \mathrm{yr}^{-1}$.

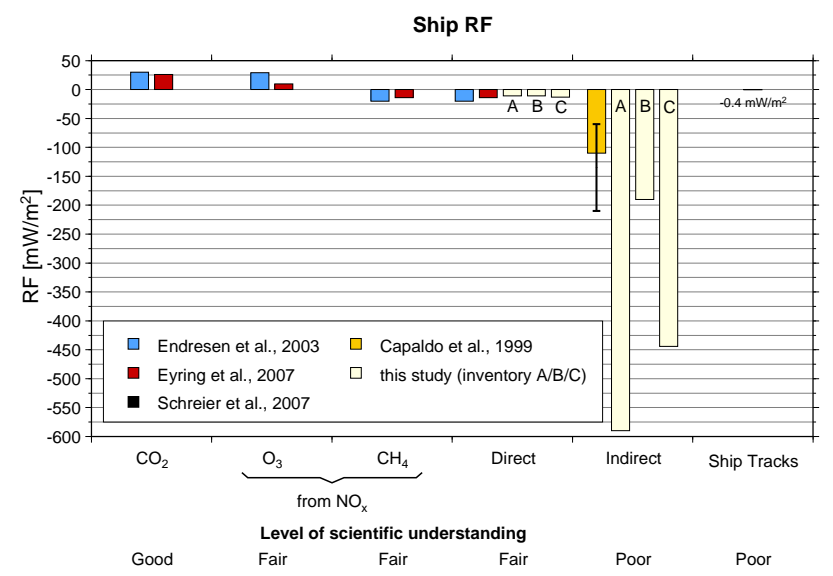

Fig. 12. Annual mean radiative forcing due to emissions from international shipping in $\mathrm{mW} \mathrm{m}^{-2}$. Values for $\mathrm{CO}_{2}, \mathrm{O}_{3}, \mathrm{CH}_{4}$ (reduced lifetime), and $\mathrm{SO}_{4}$ (direct aerosol effect) are taken from Endresen et al. (2003) and Eyring et al. (2007). The indirect aerosol effect calculated by Capaldo et al. (1999) includes the first indirect effect of sulfate plus organic material aerosols only, the error bar depicts the range spanned by their additional sensitivity studies. The estimated direct and the indirect aerosol effect calculated in this study also includes changes due to $\mathrm{BC}, \mathrm{POM}, \mathrm{NH}_{4}, \mathrm{NO}_{3}$, and $\mathrm{H}_{2} \mathrm{O}$ from shipping in addition to $\mathrm{SO}_{4}$ and refers to the changes in all-sky shortwave radiation fluxes and net cloud forcing (sum of shortwave and longwave cloud forcing) at the top of the atmosphere, respectively. The net cloud forcing is calculated from the differences in the simulated all-sky fluxes and the corresponding clear-sky fluxes at top of the atmosphere. The global annual mean RF due to ship tracks is taken from the satellite data analysis by Schreier et al. (2007). For details see text.

\section{Summary and conclusions}

In this study we used the atmospheric general circulation model ECHAM5/MESSy1 coupled to the aerosol module MADE (E5/M1-MADE) to study the impact of shipping on aerosols, clouds and the Earth's radiation budget. The aerosols calculated by E5/M1-MADE are used to drive the radiation and cloud scheme of the GCM, allowing the assessment of both, the direct and indirect aerosol effect of emissions from shipping. The evaluation of the model showed that the main features of the observed geographical patterns, seasonal cycle and vertical distribution of the basic aerosol parameters are captured. However, the comparison also unveiled existing weaknesses of the model, such as representing the optical properties of mineral dust or capturing Asian emissions of particulate matter and aerosol precursors. For the purpose of this study, these model deficiencies are acceptable when assessing the impact of shipping on aerosols and clouds by calculating differences between model simulations with and without ship emissions.

To assess uncertainties in estimates of present-day (year 2000 conditions) emission totals and spatial ship traffic 
proxies, we used three ship emission inventories, Eyring et al. (2005a) (inventory "A"), Dentener et al. (2006) (inventory "B"), and Wang et al. (2007) ${ }^{1}$ (inventory "C") and one simulation without ship emissions. The impact of emissions from international shipping on the chemical composition, particle number concentration, and size distribution of atmospheric aerosol, has been assessed by analyzing the differences between model simulations with and without shipping. The changes in aerosol properties affect the optical properties such as aerosol optical thickness of the particles (direct aerosol effect) as well as their ability to act as cloud condensation nuclei (indirect aerosol effect). Both mechanisms that impact the Earth's radiation budget are taken into account in the E5/M1-MADE simulations.

The model results reveal that the most important aerosol component from shipping is $\mathrm{SO}_{4}$, formed by the oxidation of $\mathrm{SO}_{2}$, contributing $2.3 \%$ to $3.6 \%$ of the total atmospheric sulfate burden in the simulations with different emission scenarios. The contribution of $\mathrm{BC}$ and POM from shipping is only $0.4-1.4 \%$ and $0.1-1.1 \%$, respectively. Aerosol nitrate from shipping shows the highest sensitivity to the emission inventory and contributes between $0.1 \%$ and $2.3 \%$ to the total aerosol nitrate burden. The signal from shipping decays rapidly with altitude, and is mostly limited to the lowermost $1.5 \mathrm{~km}$ in the troposphere. The model results show an increase in the Aitken mode particle number concentration of about $40 \%$ in the near surface layer above the main shipping routes in the Atlantic Ocean. The corresponding modal mean diameters of the Aitken mode decreases from $0.05 \mu \mathrm{m}$ to $0.04 \mu \mathrm{m}$ in this region. Due to subsequent growth processes, such as condensation of sulfuric acid vapor and coagulation, some particles grow into the next larger size-range of the accumulation mode, which can act as additional cloud condensation nuclei. These changes in chemical composition, particle number concentration, and size-distribution cause an increase in aerosol optical thickness above the oceans, which is related particularly to enhanced scattering of solar radiation by sulfate, nitrate, ammonium, and associated aerosol liquid water. Local changes of up to $-0.25 \mathrm{~W} / \mathrm{m}^{2}$ are simulated in individual regions such as the Gulf of Mexico, the Northeastern Pacific or the highly frequented regions in the Indian Ocean, depending on the emission inventory used. The calculated global annual average changes in the clear-sky top of the atmosphere radiative fluxes in the solar spectrum range from $-0.014 \mathrm{~W} / \mathrm{m}^{2}$ to $-0.038 \mathrm{~W} / \mathrm{m}^{2}$. The corresponding all-sky direct aerosol forcings range from $-0.011 \mathrm{~W} / \mathrm{m}^{2}$ to $-0.013 \mathrm{~W} / \mathrm{m}^{2}$.

By far the most important impact of ship emissions on the radiation budget is related to changes in the microphysical properties of low marine clouds. The simulations revealed that emissions from international shipping impact the Earth's radiation budget significantly and more than previously estimated from model studies without detailed aerosol microphysics and aerosol-cloud interaction using older ship emission inventories with lower emission totals $\left(-0.11 \mathrm{~W} / \mathrm{m}^{2}\right.$;
Capaldo et al., 1999). The changes in the radiation budget caused by modified cloud properties from the three different ship emission inventories range from $-0.19 \mathrm{~W} / \mathrm{m}^{2}$ to $-0.60 \mathrm{~W} / \mathrm{m}^{2}$. The regions affected are in particular the Northeastern Pacific off the west coast of North America, the Northeastern Atlantic, and the Atlantic off the west coast of Southern Africa. These regions are characterized by frequent occurrence of low marine clouds and coinciding high ship traffic density. The model results show that the impact of shipping is mostly confined to liquid water clouds. Ice clouds are hardly influenced. This is related to the fact that liquid water clouds are the dominant cloud type in the regions and altitude range $(<1.5 \mathrm{~km})$ predominantly affected by shipping. The additional cloud condensation nuclei from shipping increase the cloud droplet number concentration of the marine clouds, whereas the simulated liquid water content is only slightly changed. This results in a decrease in the cloud droplet effective radii, thereby increasing the reflectivity of the marine clouds and thus enhancing the shortwave cloud forcing. Sensitivity studies using pre-industrial emissions suggest that shipping contributes between $17 \%$ and $39 \%$ of the total anthropogenic indirect aerosol effect. This large contribution is related to the larger albedo changes by clouds over dark oceans than over land, and to the fact that ship emissions are released in regions with frequent occurrence of low clouds, which are highly susceptible to the enhanced aerosol number concentration in an otherwise clean marine environment. This results in a much higher response for shipping than for continental anthropogenic aerosol sources of the same source strength.

The net RF from shipping, calculated from previous estimates of the $\mathrm{RF}$ from $\mathrm{CO}_{2}, \mathrm{O}_{3}$, and $\mathrm{CH}_{4}$ from shipping as well as from the direct and indirect aerosol effect estimated here, is negative for all three emissions inventories ranging between $-0.15 \mathrm{~W} / \mathrm{m}^{2}$ and $-0.58 \mathrm{~W} / \mathrm{m}^{2}$. Further sensitivity studies with sulfur free fuel show that about $75 \%$ of the direct and indirect aerosol effect from shipping, are related to the fuel sulfur content.

Carbon dioxide's atmospheric lifetime ( $>100$ years) is much longer than global atmospheric mixing timescales, so ship $\mathrm{CO}_{2}$ emissions generate a radiative forcing in just the same way as any other $\mathrm{CO}_{2}$ source. In the future, the positive $\mathrm{RF}$ from shipping $\mathrm{CO}_{2}$ is expected to increase, because of the expected growth in the ocean-going fleet (Eyring et al., 2005b). All other RF contributions strongly depend on the technology applied. Future reductions in $\mathrm{SO}_{2}$ from ships are to be expected because of air quality issues in the vicinity of major harbors and because of the acidification of the oceans due to sulfate and sulfur emissions. The first sulfur emission control area (SECA, with only $1.5 \%$ sulfur content) in the Baltic Sea was established in May 2006. The next SECA is planned for parts of the English Channel and the North Sea and will enter into force in 2007. Furthermore, the European Union has disbanded the Directive 2005/33/EC, to limit the sulfur content to $0.1 \%$ in marine fuels for harbor 
regions in 2010. If the sulfur content of the fuel is reduced, the positive contributions to the overall RF from $\mathrm{CO}_{2}$ will remain, whereas the negative RF due to the effect on aerosols and clouds will strongly decrease. Because of air quality issues and acidification as a consequence of ship sulfur emissions, enhanced shipping with sulfur-rich fuel should not be considered as a geo-engineering strategy to decelerate global warming.

This study also showed that the geographical distribution of ship emissions over the globe plays a key role determining the global impact of shipping. The large differences in the model results obtained with three different ship emission inventories (Eyring et al., 2005a; Dentener et al., 2006, Wang et al., $2007^{1}$ ) imply a high uncertainty. Nevertheless, the main conclusions of this study hold for all three inventories. We therefore conclude that the impact of ship exhaust on atmosphere and climate has received too little attention so far and should be subject to further investigations. In particular, it remains a challenge to reduce uncertainties in present-day emission inventories, both in the emission total estimates as well as in the spatial ship traffic proxies. In addition, modeling of the indirect aerosol effect introduces many uncertainties that require improvement. Critical model parameters and processes include the aerosol size-distribution and particle number concentration (Penner et al., 2006) as well as the parameterization of aerosol activation (Lohmann and Feichter, 2005).

Acknowledgements. This work was supported by the German Helmholtz-Gemeinschaft Deutscher Forschungszentren (HGF) and the Deutsches Zentrum für Luft- und Raumfahrt (DLR) within the Young Investigators Group SeaKLIM and the project Particles and Cirrus Clouds (PAZI-2). We wish to thank the whole MESSy team of the Max Planck Institute for Chemistry in Mainz, Germany for their support and help and the Max Planck Institute for Meteorology in Hamburg, Germany for the development and provision of ECHAM5. We also kindly acknowledge the provision of MADE by the University of Cologne, Germany (RIU/EURAD-project) and thank U. Schumann and R. Sausen for very helpful discussions. All model simulations were performed on the High Performance Computing Facility (HPCF) at the European Centre for Medium-Range Weather Forecasts (ECMWF).

Edited by: J. Quaas

\section{References}

Abdul-Razzak, H. and Ghan, S. J.: A parameterization of aerosol activation, 2. Multiple aerosol types, J. Geophys. Res., 105(D5), 6837-6844, 2000.

Ackerman, A. S., Kirkpatrick, M. P., Stevens, D. E., and Toon, O. B.: The impact of humidity above stratiform clouds on indirect climate forcing, Nature, 432, 1014-1017, 2004.

Ackermann, I. J., Hass, H., Memmesheimer, M., Ziegenbein, C., and Ebel, A.: Modal Aerosol Dynamics for Europe: Development and first applications, Atmos. Environ., 32, 2981-2999, 1998.
Barkstrom, B. R.: The Earth Radiation Budget Experiment (ERBE), Bull. Amer. Meteor. Soc., 65, 1170-1185, 1984.

Bennartz, R.: Global assessment of marine boundary layer cloud droplet number concentration from satellite, J. Geophys. Res., 112, D02201, doi:10.1029/2006JD007547, 2007.

Capaldo, K., Corbett, J. J., Kasibhatla, P., Fischbeck, P. S., and Pandis, S. N.: Effects of ship emissions on sulfur cycling and radiative climate forcing over the ocean, Nature, 400, 743-746, 1999.

Clarke, A. D. and Kapustin, V. N.: A Pacific Aerosol Survey. Part I: A Decade of Data on Particle Production, Transport, Evolution, and Mixing in the Troposphere, J. Atmos. Sci., 59, 363382, 2002.

Conover, J. H.: Anomalous Cloud Lines, J. Atmos. Sci., 23, 778785, 1966.

Corbett, J. J. and Köhler, H. W.: Updated emissions from ocean shipping, J. Geophys. Res., 108(D20), 4650, doi:10.1029/2003JD003751, 2003.

Corbett, J. J. and Köhler, H. W.: Considering alternative input parameters in an activity-based ship fuel consumption and emission model: Reply to comment by Øyvind Endresen et al. on "Updated emissions from ocean shipping”, J. Geophys. Res., 109, D23303, doi:10.1029/2004JD005030, 2004.

Dentener, F., Kinne, S., Bond, T., Boucher, O., Cofala, J., Generoso, S., Ginoux, P., Gong, S., Hoelzemann, J. J., Ito, A., Marelli, L., Penner, J. E., Putaud, J.-P., Textor, C., Schulz, M., van der Werf, G. R., and Wilson, J.: Emissions of primary aerosol and precursor gases in the years 2000 and 1750, prescribed data-sets for AeroCom, Atmos. Chem. Phys., 6, 4321-4344, 2006,

http://www.atmos-chem-phys.net/6/4321/2006/.

Durkee, P. A., Chartier, R. E., Brown, A., Trehubenko, E. J., Rogerson, S. D., Skupniewicz, C., Nielsen, K. E., Platnick, S., and King, M. D.: Composite Ship-Track Characteristics, J. Atmos. Sci., 57, 2542-2553, 2000.

Endresen, Ø., Sørgård, E., Sundet, J. K., Dalsøren, S. B., Isaksen, I. S. A., Berglen, T. F., and Gravir, G.: Emission from international sea transportation and environmental impact, J. Geophys. Res., 108(D17), 4560, doi:10.1029/2002JD002898, 2003.

Endresen, Ø., Sørgård, E., Bakke, J., and Isaksen, S. A.: Substantiation of a lower estimate for the bunker inventory: Comment on "Updated emissions from ocean shipping" by J. J. Corbett and H. W. Koehler, J. Geophys. Res., 109, D23302, doi:10.1029/2004JD004853, 2004.

EPA (Environmental Protection Agency, USA): SPECIATE 3.2, profiles of total organic compounds and particulate matter, http: //www.epa.gov/ttn/chief/software/speciate/index.html, 2002.

Eyring, V., Köhler, H. W., van Aardenne, J., and Lauer, A.: Emissions from international shipping, Part 1: The last 50 years, J. Geophys. Res., 110, D17305, doi:10.1029/2004JD005619, 2005a.

Eyring, V., Köhler, H. W., Lauer, A., and Lemper, B.: Emissions From International Shipping: 2. Impact of Future Technologies on Scenarios Until 2050, J. Geophys. Res., 110, D17306, doi:10.1029/2004JD005620, 2005b.

Eyring, V., Stevenson, D. S., Lauer, A., Dentener, F. J., Butler, T., Collins, W. J., Ellingsen, K., Gauss, M., Hauglustaine, D. A., Isaksen, I. S. A., Lawrence, M. G., Richter, A., Rodriguez, J. M., Sanderson, M., Strahan, S. E., Sudo, K., Szopa, S., van Noije, T. P. C., and Wild, O.: Multi-model simulations of the impact of international shipping on atmospheric chemistry and climate in 
2000 and 2030, Atmos. Chem. Phys., 7, 757-780, 2007, http://www.atmos-chem-phys.net/7/757/2007/.

Hobbs, P. V., Garrett, T. J., Ferek, R. J., Strader, S. R., Hegg, D. A., Frick, G. M., Hoppel, W. A., Gasparovic, R. F., Russel, L. M., Johnson, D. W., O’Dowd, C., Durkee, P. A., Nielsen, K. E., and Innis, G.: Emissions from ships with their respect to clouds, J. Atmos. Sci., 57, 2570-2590, 2000.

Holben, B., Eck, T., Slutsker, I., Tanre, D., Buis, J., Vermote, E., Reagan, J., Kaufman, Y., Nakajima, T., Lavevau, F., Jankowiak, I., and Smirnov, A.: AERONET - A federated instrument network and data archive for aerosol characterization, Rem. Sens. Environ., 66, 1-16, 1998.

Intergovernmental Panel on Climate Change (IPCC): Climate Change 2007: The Physical Science Basis, Contribution of Working Group I to the Fourth Assessment Report of the Intergovernmental Panel on Climate Change, edited by: Solomon, S., Qin, D., Manning, M., Chen, Z., Marquis, M., Averyt, K. B., Tignor, M., and Miller, H. L., Cambridge University Press, Cambridge, United Kingdom and New York, NY, USA, 996 pp, 2007.

Jöckel, P., Sander, R., Kerkweg, A., Tost, H., and Lelieveld, J.: Technical Note: The Modular Earth Submodel System (MESSy) - a new approach towards Earth System Modeling, Atmos. Chem. Phys., 5, 433-444, 2005, http://www.atmos-chem-phys.net/5/433/2005/.

Jöckel, P., Tost, H., Pozzer, A., Brühl, C., Buchholz, J., Ganzeveld, L., Hoor, P., Kerkweg, A., Lawrence, M. G., Sander, R., Steil, B., Stiller, G., Tanarhte, M., Taraborrelli, D., van Aardenne, J., and Lelieveld, J.: The atmospheric chemistry general circulation model ECHAM5/MESSy1: consistent simulation of ozone from the surface to the mesosphere, Atmos. Chem. Phys., 6, 50675104, 2006, http://www.atmos-chem-phys.net/6/5067/2006/.

Kahn, R., Banerjee, P., McDonald, D., and Diner, D. J.: Sensitivity of multi-angle imaging to aerosol optical depth and to pure particle size distribution and composition over ocean, J. Geophys. Res., 103, 32 195-32 213, 1998.

Kaufman, Y., Tanre, D., Remer, L., Vermote, E., Chu, D., and Holben, B.: Operational remote sensing of tropospheric aerosol over the land from EOS-MODIS, J. Geophys. Res., 102, 17 051$17061,1997$.

Kerkweg, A., Buchholz, J., Ganzeveld, L., Pozzer, A., Tost, H., and Jöckel, P.: Technical Note: An implementation of the dry removal processes DRY DEPosition and SEDImentation in the Modular Earth Submodel System (MESSy), Atmos. Chem. Phys., 6, 4617-4632, 2006a.

Kerkweg, A., Sander, R., Tost, H., and Jöckel, P.: Technical note: Implementation of prescribed (OFFLEM), calculated (ONLEM), and pseudo-emissions (TNUDGE) of chemical species in the Modular Earth Submodel System (MESSy), Atmos. Chem. Phys., 6, 3603-3609, 2006b.

Khairoutdinov, M. and Kogan, Y.: A new cloud physics parameterization in a large eddy simulation model of marine stratocumulus, Mon. Weather Rev., 128, 229-243, 2000.

Kinne, S., Schulz, M., Textor, C., Guibert, S., Balkanski, Y., Bauer, S. E., Berntsen, T., Berglen, T. F., Boucher, O., Chin, M., Collins, W., Dentener, F., Diehl, T., Easter, R., Feichter, J., Fillmore, D., Ghan, S., Ginoux, P., Gong, S., Grini, A., Hendricks, J., Herzog, M., Horowitz, L., Isaksen, I., Iversen, T., Kirkevåg, A., Kloster, S., Koch, D., Kristjansson, J. E., Krohl, M., Lauer, A., Lamarque,
J. F., Lesins, G., Liu, X., Lohmann, U., Montanaro, V., Myhre, G., Penner, J. E., Pitari, G., Reddy, S., Seland, O., Stier, P., Takemura, T., and Tie, X.: An AeroCom initial assessment - optical properties in aerosol component modules of global models, Atmos. Chem. Phys., 6, 1815-1834, 2006,

http://www.atmos-chem-phys.net/6/1815/2006/.

Lauer, A., Hendricks, J., Ackermann, I., Schell, B., Hass, H., and Metzger, S.: Simulating aerosol microphysics with the ECHAM/MADE GCM - Part I: Model description and comparison with observations, Atmos. Chem. Phys., 5, 3251-3276, 2005, http://www.atmos-chem-phys.net/5/3251/2005/.

Lauer, A. and Hendricks, J.: Simulating aerosol microphysics with the ECHAM4/MADE GCM - Part II: Results from a first multiannual simulation of the submicrometer aerosol, Atmos. Chem. Phys., 6, 5495-5513, 2006,

http://www.atmos-chem-phys.net/6/5495/2006/.

Lawrence, M. G. and Crutzen, P. J.: Influence of $\mathrm{NO}_{\mathrm{x}}$ emissions from ships on tropospheric photochemistry and climate, Nature, 402, 167-170, 1999.

Lloyd's Maritime Information System (LMIS): The Lloyd's Maritime Database [CD-ROM], Lloyd's Register - Fairplay Ltd., London, 2002.

Lohmann, U. and Feichter, J.: Global indirect aerosol effects: A review, Atmos. Chem. Phys., 5, 715-737, 2005, http://www.atmos-chem-phys.net/5/715/2005/.

Lohmann, U., Feichter, J., Chuang, C. C., and Penner, J. E.: Prediction of the number of cloud droplets in the ECHAM GCM, J Geophys. Res., 104, 9169-9198, 1999.

Lohmann, U.: Possible aerosol effects on ice clouds via contact nucleation, J. Atmos. Sci., 59, 647-656, 2002.

Martonchik, J. V., Diner, D. J., Kahn, R. A., Ackerman, T. P., Verstraete, M. E., Pinty, B., and Gordon, H. R.: Techniques for the retrieval of aerosol properties over land and ocean using multiangle imaging, IEEE Trans. Geosci. Rem. Sensing, 36, 1212 1227, 1998.

Metzger, S., M., Dentener, F. J., Lelieveld, J., and Pandis, S. N.: Gas/aerosol partitioning I: A computationally efficient model, J. Geophys. Res., 107(D16), 4312, doi:10.1029/2001JD001102, 2002.

Minikin, A., Petzold, A., Ström, J., Krejci, R., Seifert, M., Velthoven, P. v., Schlager, H., and Schumann, U.: Aircraft Observations of the Upper Tropospheric Fine Particle Aerosol in the Northern and Southern Hemispheres at Midlatitudes, Geophys. Res. Lett., 30(10), 1503, doi:10.1029/2002GL016458, 2003.

Nakajima, T. Y. and Nakajima, T.: Wide-Area determination of cloud microphysical properties from NOAA AVHRR measurements for FIRE and ASTEX regions, J. Atmos. Sci., 52, $4043-$ 4059, 1995.

Olivier, J. G. J., van Aardenne, J. A., Dentener, F., Ganzeveld, L., and Peters, J. A. H. W.: Recent trends in global greenhouse gas emissions: regional trends and spatial distribution of key sources, in: Non- $\mathrm{CO}_{2}$ Greenhouse Gases (NCGG-4), van Amstel, A. (coord.), 325-330, Millpress, Rotterdam, ISBN 905966 043 9, 2005.

Penner, J. E., Quaas, J., Storelvmo, T., Takemura, T., Boucher, O., Guo, H., Kirkevåg, A., Kristjánsson, J. E., and Seland, Ø.: Model intercomparison of indirect aerosol effects, Atmos. Chem. Phys., 6, 3391-3405, 2006,

http://www.atmos-chem-phys.net/6/3391/2006/. 
Roeckner, E., Brokopf, R., Esch, M., Giorgetta, M., Hagemann, S., Kornblueh, L., Manzini, E., Schlese, U., and Schulzweida, U.: Sensitivity of Simulated Climate to Horizontal and Vertical Resolution in the ECHAM5 Atmosphere model, J. Climate, 19, 3771-3791, 2006.

Rossow, W. B., Walker, A. W., Beuschel, D. E., and Roiter, M. D.: International Satellite Cloud Climatology Project (ISCCP) Documentation of New Cloud Datasets, WMO/TD-No. 737, World Meteorological Organization, 115 pp, 1996.

Sander, R., Kerkweg, A., Jöckel, P., and Lelieveld, J.: Technical Note: The new comprehensive atmospheric chemistry module MECCA, Atmos. Chem. Phys., 5, 445-450, 2005, http://www.atmos-chem-phys.net/5/445/2005/.

Sausen, R., Isaksen, I. S. A., Grewe, V., Hauglustaine, D. A., Lee, D. S., Myhre, G., Köhler, M. O., Pitari, G., Schumann, U., Stordal, F., and Zerefos, C.: Aviation radiative forcing in 2000: An update on IPCC (1999), Meteorol. Z., 14, 555-561, 2005.

Schreier, M., Kokhanovsky, A. A., Eyring, V., Bugliaro, L., Mannstein, H., Mayer, B., Bovensmann, H., and Burrows, J. P.: Impact of ship emissions on the microphysical, optical and radiative properties of marine stratus: a case study, Atmos. Chem. Phys., 6, 4925-4942, 2006, http://www.atmos-chem-phys.net/6/4925/2006/.

Schreier, M., Mannstein, H., Eyring, V., and Bovensmann, H.: Global ship track distribution and radiative forcing from 1-year of AATSR-data, Geophys. Res. Lett., 34, L17814, doi:10.1029/2007GL030664, 2007.

Sundqvist, H., Berge, E., and Kristiansson, J. E.: Condensation and Cloud Parameterization Studies with a Mesoscale Numerical Weather Prediction Model, Mon. Weather Rev., 117, 1641-1657, 1989.
Tanre, D., Kaufman, Y. J., Herman, M., and Mattoo, S.: Remote Sensing of aerosol properties over ocean using the MODIS/EOS spectral radiances, J. Geophys. Res., 102, 16 971-16988, 1997.

Textor, C., Schulz, M., Guibert, S., Kinne, S., Balkanski, Y., Bauer, S., Berntsen, T., Berglen, T., Boucher, O., Chin, M., Dentener, F., Diehl, T., Easter, R., Feichter, H., Fillmore, D., Ghan, S., Ginoux, P., Gong, S., Grini, A., Hendricks, J., Horowitz, L., Huang, P., Isaksen, I., Iversen, T., Kloster, S., Koch, D., Kirkevåg, A., Kristjansson, J. E., Krol, M., Lauer, A., Lamarque, J. F., Liu, X., Montanaro, V., Myhre, G., Penner, J., Pitari, G., Reddy, S., Seland, Ø., Stier, P., Takemura, T., and Tie, X.: Analysis and quantification of the diversities of aerosol life cycles within AeroCom, Atmos. Chem. Phys., 6, 1777-1813, 2006, http://www.atmos-chem-phys.net/6/1777/2006/.

Tost, H., Jöckel, P., Kerkweg, A., Sander, R., and Lelieveld, J.: Technical note: A new comprehensive SCAVenging submodel for global atmospheric chemistry modelling, Atmos. Chem. Phys., 6, 565-574, 2006, http://www.atmos-chem-phys.net/6/565/2006/.

Tost, H., Jöckel, P., Kerkweg, A., Pozzer, A., Sander, R., and Lelieveld, J.: Global cloud and precipitation chemistry and wet deposition: tropospheric model simulations with ECHAM5/MESSy1, Atmos. Chem. Phys., 7, 2733-2757, 2007, http://www.atmos-chem-phys.net/7/2733/2007/.

Twomey, S., Howell, H. B., and Wojciechowski, T. A.: Comments on anomalous cloud lines, J. Atmos. Sci., 25, 333-334, 1968.

Van Aardenne, J. A., Dentener, F. J., Olivier, J. G. J., Klein Goldewijk, C. G. M., and Lelieveld, J.: A $1 \times 1$ degree resolution dataset of historical anthropogenic trace gas emissions for the period 1890-1990, Global Biogeochem. Cycles, 15(4), 909-928, 2001. 